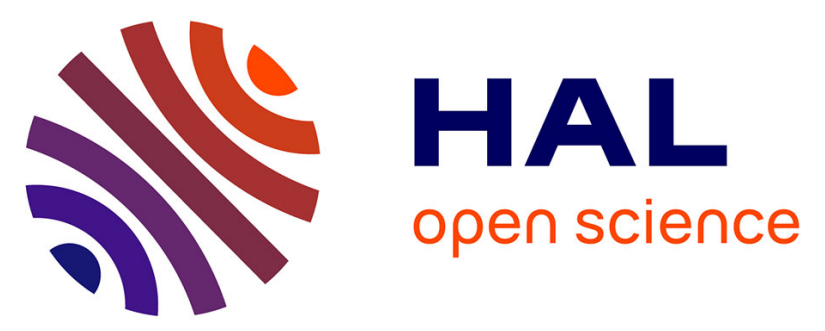

\title{
Biogeochemical Processes in a Clay Formation In-Situ Experiment: Part E - Equilibrium Controls on Chemistry of Pore Water from the Opalinus Clay, Mont Terri Underground Research Laboratory, Switzerland
}

F.J. Pearson, Christophe Tournassat, Eric C. Gaucher

\section{To cite this version:}

F.J. Pearson, Christophe Tournassat, Eric C. Gaucher. Biogeochemical Processes in a Clay Formation In-Situ Experiment: Part E - Equilibrium Controls on Chemistry of Pore Water from the Opalinus Clay, Mont Terri Underground Research Laboratory, Switzerland. Applied Geochemistry, 2011, 26, pp.990-1008. 10.1016/j.apgeochem.2011.03.008 . hal-00597132

\section{HAL Id: hal-00597132 \\ https://hal-brgm.archives-ouvertes.fr/hal-00597132}

Submitted on 31 May 2011

HAL is a multi-disciplinary open access archive for the deposit and dissemination of scientific research documents, whether they are published or not. The documents may come from teaching and research institutions in France or abroad, or from public or private research centers.
L'archive ouverte pluridisciplinaire HAL, est destinée au dépôt et à la diffusion de documents scientifiques de niveau recherche, publiés ou non, émanant des établissements d'enseignement et de recherche français ou étrangers, des laboratoires publics ou privés. 


\title{
Biogeochemical Processes in a Clay Formation In-Situ Experiment: Part E - Equilibrium Controls on Chemistry of Pore Water from the Opalinus Clay, Mont Terri Underground Research Laboratory, Switzerland
}

\author{
F. J. Pearson ${ }^{1}$, Christophe Tournassat ${ }^{2}$, Eric Gaucher ${ }^{2}$ \\ ${ }^{1}$ Ground-Water Geochemistry, 5108 Trent Woods Dr., New Bern, NC 28562 USA \\ ${ }^{2}$ BRGM, B. P. 36009, 45060 Orleans Cedex 2, France
}

\section{REVISED IN RESPONSE TO REFEREES' COMMENTS}

14 September 2010

\begin{abstract}
The chemistry of pore water (particularly $\mathrm{pH}$ and ionic strength) is an important property of clay rocks being considered as host rocks for long-term storage of radioactive waste. Pore waters in clay-rich rocks generally cannot be sampled directly. Instead, their chemistry must be found using laboratory-measured properties of core samples and geochemical modelling. Many such measurements have been made on samples from the Opalinus Clay from the Mont Terri URL. Several boreholes in that URL yielded water samples against which pore water models have been calibrated. Following a first synthesis report published in 2003 (Pearson, F. J., et al.., 2003. Mont Terri project - Geochemistry of water in the Opalinus clay formation at the Mont Terri Rock Laboratory. Geology Series No. 5 Swiss Federal Office for Water and Geology, Bern.), this paper presents the evolution of the modelling approaches developed within Mont-Terri URL scientific programs through the last decade (1997-2009). Models are compared to the composition of waters sampled during dedicated borehole experiments. Reanalysis of the models, parameters and database enabled the principal shortcomings of the previous modelling efforts to be overcome. The inability to model the potassium concentrations correctly with the measured cation exchange properties was found to be due to the use of an inappropriate selectivity coefficient for Na-K exchange; the inability to reproduce the measured carbonate chemistry and $\mathrm{pH}$ of the pore waters using mineral-water reactions alone was corrected by considering clay mineral equilibria as done by Gaucher et al. (Gaucher, E. C., Tournassat, C., Pearson, F. J., Blanc, P., Crouzet, C., Lerouge, C., and Altmann, S., 2009. A robust model for clayrock porewater chemistry. Geochimica \& Cosmochimica Acta 73, 6470-6483). Re-examination of the measured calcium/magnesium activity ratios and consideration of the mineralogical composition of the Opalinus Clay
\end{abstract}


suggested that calcium/magnesium cation exchange rather than dolomite saturation may control the ratio of these ions in solution. This re-examination also suggests that the calcium/magnesium ratio decreases with increasing pore water salinity. Several possible reasons for this are proposed. Moreover, it is demonstrated that feldspar equilibria must not be included in Opalinus Clay modelling because feldspars are present only in very small quantities in the formation and because sodium/potassium ratios measured in pore water samples are inconsistent with feldspar saturation. The principal need to improve future modelling is additional or better data on rock properties, in particular: (i) a more detailed identification of phases in the Opalinus Clay that include redox-sensitive elements together with evaluation of their thermodynamic properties; (ii) an improved understanding of the distribution of celestite throughout the Opalinus Clay for $\mathrm{Sr} /$ sulphate concentrations control; (iii) improvements in analytic and thermodynamic data for Ca-Mg rock cation exchange and mineral chemical properties and (iv) the measurement of composition and stability constants of clay minerals actually present in the formation. 


\section{INTRODUCTION}

A significant difference between the pore water in clay-rich rocks and conventional ground water is the operation by which their chemistry is characterized. Ground-water samples are commonly available from wells and springs in volumes that are large enough for the performance of many field analyses and that permit collection of samples for a variety of laboratory analyses. Pore waters from clay-rich rocks, on the other hand, can rarely be sampled directly and then only in small volumes which have usually been affected by exposure to the sampling environment. Aqueous equilibrium modelling has long been applied to ground waters to investigate mineral and other controls on their measured compositions and the extent to which they are in equilibrium with their environments. For clay-rock pore water, geochemical modelling is also applied to determine the chemistry of waters that cannot be sampled directly. While geochemical modelling is commonly used to test the extent to which ground waters are in water-rock equilibrium, geochemical modelling of pore waters usually assumes that mineral-water reactions are in equilibrium.

One of the principal objectives of the research programme at the Mont Terri Underground Research Laboratory (URL) (http://www.mont-terri.ch/) was to develop techniques to characterize the chemistry of pore water in clay-rich, low-permeability rocks and, by applying these techniques, to characterize the porewater chemistry of the Opalinus Clay at Mont Terri. A variety of techniques was anticipated. These included direct analyses of water seeping into boreholes drilled from the underground laboratory, of water ejected from core samples subjected to high-pressure squeezing, and of water expelled from core samples during high-pressure infiltration experiments. Indirect approaches included aqueous leaching of core samples to determine the soluble salt contents of the rocks and leaching with solutions that extracted exchangeable cations. Equilibrium modelling was used to evaluate the water analyses with respect to equilibria with formation minerals and cation exchange properties and for consistency between measured and calculated values of such properties as $\mathrm{PCO}_{2}$.

The properties of the Opalinus Clay at the Mont Terri URL are such that pore water samples can be collected from boreholes drilled within the laboratory. These samples provide validation for calculations of pore-water chemistry based on measured properties of the Opalinus Clay itself. Such calculation methods, once validated, can be applied to other clay rock pore waters from which direct samples cannot be collected.

Studies are also in progress at a number of other clay sites many of which have recently been described by Mazurek et al. (2009). Clays at several sites including the Callovo-Oxfordian at the Site Meuse/Haute Marne (Bure), France, and the Boom Clay at Mol, Belgium, yield water to boreholes drilled from underground laboratories, as does the Opalinus Clay. The pore water chemistry of these units can be 
determined directly. Clays at other sites are more indurated and do not yield water to boreholes drilled into unfractured, bulk rock. These include the Toarcian-Domerian at Tournemire, France, and two other clays not described by Mazurek et al. (2009), the Helvetic marls (Palfris marl) at Wellenberg, Switzerland, (Nagra 1997) and the upper Ordovician Queenston and adjacent shales at the Bruce Site, Ontario (Jensen et al. 2010). To characterize the pore water from such indurated units will require calculations based on rock properties like those described here.

This paper discusses the state of equilibrium modelling of pore-water chemistry. The emphasis is on the experience gained from work at Mont Terri but similar modelling of other units is also referred to as it supports the Mont Terri work.

\subsection{Chemistry of Opalinus Clay pore water}

The geology and the layout of the Mont Terri URL are summarized by Wersin et al.(This issue). The porewater chemistry and properties of the host rock that are relevant to the water chemistry are given by Pearson et al. (2003), Wersin et al. (2009) and Koroleva et al.(this issue). Degueldre et al. (2003) also discuss the water chemistry at Mont Terri based only on samples from boreholes in the Opalinus Clay and seeps in the adjacent limestones. Water chemical data are based on analyses and in situ measurements on water flowing from four boreholes drilled from the URL, from samples of drill core squeezed at high pressures and from aqueous leaching of core samples.

As shown in Figure 2 of Wersin et al. (this issue), the chloride contents of pore water in the clay rocks at Mont Terri vary from about $13 \mathrm{~g} / \mathrm{L}$ near the contact between the Opalinus Clay and the Lias to less than 1 $\mathrm{g} / \mathrm{L}$ at the contacts of the clays with the limestone aquifers overlying and underlying the clay units. This pattern is considered to result from diffusion of solutes from initially saline pore water throughout the clayrich units to fresh water the in adjacent aquifers. Such diffusion has been modelled by Mazurek et al. (2009, Sect. 2.4 \& 5.4) using transport parameters measured on samples from Mont Terri and seawater as the initial pore-water. The measured profile could be matched by assuming that fresh water first invaded the upper aquifer at about $6.5 \mathrm{Ma}$ and the lower aquifer at about $0.5 \mathrm{Ma}$. The different times for the initiation of diffusion are consistent with the geologic history of the region and account for the asymmetry of the $\mathrm{Cl}$ profile.

Of the several types of water samples available, those from the boreholes best represent in situ pore-water chemistry because they were collected with the least disturbance to parameters such as $\mathrm{pH}$, redox state and gas compositions that are sensitive to sample handling. The boreholes are designated BWSA-3, which is located at a distance of about $40 \mathrm{~m}$ as shown on Figure 2 of Wersin et al.(this issue), BWSA-2, at about 60 
$\mathrm{m}, \mathrm{BWSA}-1$, at about $100 \mathrm{~m}$, and PC-C ,at about $110 \mathrm{~m}$. Waters from these boreholes have chloride contents ranging from about $4.4 \mathrm{~g} / \mathrm{L}$ in BWSA-3 to about $11.6 \mathrm{~g} / \mathrm{L}$ in PC-C.

One of the major differences between laboratory-collected and borehole water samples was that sulphate concentrations based on core leaching and squeezing were commonly higher than those in corresponding borehole samples. Figure 1 shows the mole ratios of sulphate/chloride and of bromide/chloride plotted against chloride concentrations. The dashed lines in this figure represent the ion ratios in normal seawater. The bromide/chloride ratio of all samples is essentially that of seawater indicating that the dissolved salts in the pore water had a seawater origin and that the pore water has not been subject to salt dissolution nor to any physical processes that would fractionate bromide and chloride. The lowest sulphate/chloride ratios are about that of seawater but there are also are a number of samples with higher relative sulphate contents. These occur in samples collected by core squeezing, in samples from the lower-chloride boreholes BWSA-2 and BWSA-3, and in samples with low $\mathrm{Cl}$ contents from seeps in the Mont Terri laboratory from units above and below the clay units (Wersin et al. This issue, Figure 2).

The Opalinus Clay contains pyrite which is known to oxidize readily when clay rock containing it is exposed to the atmosphere (Baeyens et al, (1985b). The relatively higher sulphate contents of the squeezed samples shown in Figure 1 are attributed to the oxidation of pyrite during core preparation and squeezing. The relatively low sulphate squeezed samples were prepared using a technique which protected the core from contact with the atmosphere during both preparation and squeezing. The agreement between the ratios in the protected, squeezed samples and the water samples collected from the boreholes indicates that pyrite oxidation did not contribute significantly to the sulphate contents of either of these types of samples.

The diffusion model is consistent with the seawater bromide/chloride ratio of the pore water samples in that sea water in that seawater was chosen as the composition of the initial water and the pore water should retain this bromide/chloride ratio during diffusion because the diffusion properties of chloride and bromide are closely similar.

The chemistry of the PC-C, BWSA-1 and BWSA-3 waters is given in Table 1. The average and one standard deviation values are those of samples taken from the PC-C borehole from 2004 through 2007 (Vinsot et al. 2008a Tab 2), and from the BWSA-1 and BWSA-3 boreholes from 1998 through 2000 (Pearson et al. 2003 Annex 1) and from 2003 through 2006 (Wersin et al. 2009 Tab 3.9 and 3.12). The BWSA-2 borehole yielded water of composition intermediate between those of BWSA-1 and BWSA-3 and is not included in Table 1. Analyses for samples from this borehole are given by (Pearson et al. 2003 Annex 1). The chemistry of all three BWSA boreholes is illustrated in Figure 2. 
The PC-C borehole was constructed to minimize possible oxidation and bacterial contamination, and was instrumented for in situ measurements (Vinsot et al. 2008a). Samples from this borehole are thought to be less subject to artefacts than those from the earlier boreholes which were constructed with fewer precautions. Therefore, the modelling in this paper has been tested against PC-C water chemistry. Modelling similar to that described here has also been tested against the chemistry of BWSA-1 and - 3 water as described in Chapter 3 of Wersin at al. (2009).

\section{EQUILIBRIUM MODELLING OF CLAY PORE WATER.}

Calculations of clay-rock pore-water chemistry are based on equilibrium thermodynamic modelling of water-rock reactions which control the pore-water chemistry. Generations of studies of conventional ground waters have demonstrated equilibrium between the water and many aquifer minerals. Equilibrium between pore water and minerals in many clay rocks is even more likely than between ground waters and aquifer minerals because the residence times of pore waters in poorly-permeable clay rocks are typically considerably larger than those of ground waters. Furthermore, the grain size of reactive minerals in clay rocks is commonly smaller than that of typical aquifer rocks.

Gibbs' Phase Rule provides a convenient formal framework within which to discuss equilibrium modelling of clay pore water. It is written:

$$
\mathrm{F}=\mathrm{C}+2-\mathrm{P}
$$

where $\mathrm{F}$ is the variance or the number of degrees of freedom of the system, $\mathrm{C}$ is the number of components, and $\mathrm{P}$ is the number of phases in equilibrium with each other. For a system at a fixed temperature and pressure in which all components are controlled by water-rock reactions $\mathrm{P}=\mathrm{C}$, where $\mathrm{P}$ is the number of phases, including the solution.

Most ground waters and pore waters contain solutes such as chloride and bromide that are commonly not controlled by water-rock reactions. In the absence of evaporite minerals, such solutes, which correspond to the "mobile" components of metamorphic petrology, each adds a degree of freedom to the system (Thompson 1955). To model equilibrium, the concentrations of free components must be fixed as must the system temperature and pressure,.

Several types of reactions can be distinguished. One comprises homogeneous reactions in the solution phase such as ion-pairing, or solute speciation, and oxidation-reduction reactions. Two types of heterogeneous reactions are also considered. One includes mineral and gas dissolution and precipitation reactions which are also the dominant controls on ground waters. The other includes cation exchange reactions. While these 
also contribute to the properties of many ground waters, they are vital to understanding the behaviour of pore waters in clay rocks.

Calculations of mineral and gas equilibria with ground waters and of ion-pairing have been made for more than 40 years (e.g. Garrels and Christ 1965, Garrels and Thompson 1962). Reactions of these types are included in the aqueous computer modelling programs that are widely available and commonly used. Thermodynamic databases both for hand calculations and in formats compatible with aqueous modelling programs were developed to support the earliest calculations and are being continuously expanded and improved. Modelling techniques for these equilibria are so widely known as to require no additional discussion here.

Cation exchange reactions have long been recognized as important in controlling soil- and ground-water chemistry (e. g. Way 1852, Foster 1950, Pearson and White 1967) but their inclusion in equilibrium computer models is more recent (Thorstenson et al. 1979; Appelo et al. 1989). Methods for modelling cation exchange reactions and for developing the often site-specific data needed are less well-known and will be discussed here.

\subsection{EARLY MODELLING}

\subsubsection{Calculating water chemistry from core properties}

The first modelling of pore water in the Opalinus Clay from Mont Terri was by Bradbury et al.(1997-1998) and Bradbury and Baeyens (1998). It was undertaken before water samples were available and was based on the properties of the rock itself. These authors assumed that the water would be in equilibrium with such reactive minerals as calcite, which are known to be in equilibrium with many ground waters. In addition, they expected the pore water to be in cation-exchange equilibrium with the clay of the formation so that the exchangeable cation composition of the formation would be a "fingerprint" of the ratios of dissolved cations. Cation exchange equilibria had previously been considered in estimating the compositions of pore waters in the Boom Clay at the underground research laboratory operated by the Belgian Nuclear Research Centre $(\mathrm{SCK} \cdot \mathrm{CEN})$ at Mol-Dessel, Belgium (Baeyens et al.1985a) and in the Helvetic marls (Palfris formation) at Wellenberg, Switzerland (Baeyens and Bradbury (1994).

The properties needed to support their modelling were the formation mineralogy and exchangeable cation populations, and the aqueous concentrations of "free" solutes such as chloride. These were measured on a sample from a core taken during the drilling of borehole BWSA-1 described above

The mineralogy was based on microscopic and x-ray determinations. Bradbury and Baeyens determined the exchangeable cation contents by leaching with solutions of Ni-ethylenediamine (Ni-en) which displaces 
exchangeable cations. Leaching with pure water was also done at several rock-leachate ratios. "Mobile" solutes were identified as those with aqueous leachate concentrations that changed linearly with the rockleachate ratio. When expressed per mass of rock leached, the concentrations of such solutes do not change with the rock-leachate ratio. These solutes were chloride and sulphate which had concentrations of $12.3 \pm$ 1.6 and $1.85 \pm 0.2 \mathrm{mmol} / \mathrm{kg}$ rock, respectively in the core sample examined.. The apparent rock concentrations of other solutes varied with the rock-leachate ratio indicating reactions between the leachate and the rock.

To calculate the pore water concentrations of chloride and sulphate from their concentrations in the rock requires knowledge of the anion-bearing porosity of the rock as discussed by Pearson (1999) and Pearson et al. (2003 Annex 10). This information was not available to Bradbury and Baeyens, so they assumed anionbearing porosities from 10 to $14 \%$. These led to pore-water concentrations from 0.216 to $0.394 \mathrm{~mol} / \mathrm{L}(\mathrm{M})$ chloride and from 0.022 to $0.033 \mathrm{M}$ sulphate in their sample of core. It was necessary that the highest sulphate concentrations, those corresponding to the lowest porosities, be adjusted downward during equilibrium modelling so that the calculated pore waters would not be oversaturated with respect to gypsum. Because gypsum is absent from undisturbed rock at Mont Terri, apparent gypsum saturation suggested that aqueous leaching overestimated the sulphate content of in situ pore water. Bradbury and Baeyens noted that although stringent precautions were taken to minimize contact of core material with the atmosphere, some oxidation of pyrite present in the Opalinus clay could not be ruled out.

There are three sources for the cations contained in the Ni-en leachate solutions: cations displaced from exchange sites by the $\mathrm{Ni}$-en, cations dissolved in the pore water in the sample, and cations resulting from mineral dissolution and precipitation reactions with the Ni-en leaching solution. Bradbury and Baeyens assumed that cation exchange reactions occurred more rapidly than dissolution/precipitation reactions. Thus, they calculated exchangeable cation occupancies from leachates made for the relatively short time of seven days and corrected them for the solutes in the in situ pore water by assuming either that both chloride and sulphate were balanced by sodium or that chloride was balanced by sodium and sulphate by calcium. Although these assumptions led to different exchangeable cation populations and selectivity coefficients, their effects on the calculated water composition were within the range of those estimated from other laboratory uncertainties.

Cation exchange selectivity coefficients were found from the exchangeable cation populations and compositions of the aqueous leachate solutions. These were defined relative to sodium and written:

$$
K^{N a^{+} / K^{+}}=\frac{a_{N a^{+}}}{a_{K^{+}}} \times \frac{a_{K X}}{a_{N a X}} \text { and } K^{N a^{+} / M^{2+}}=\frac{a_{N a^{+}}^{2}}{a_{M^{2+}}} \times \frac{a_{M X_{2}}}{a_{N a X}^{2}}
$$


In these equations, $\mathrm{M}^{2+}$ is any divalent cation, $\mathrm{X}$ represents a negatively charged exchange site and all quantities on the right are activities. Bradbury and Baeyens used the Gaines-Thomas convention in which activities of exchanged cations are assumed to equal their equivalent fractional occupancies (Gaines and Thomas 1953). The selectivity coefficients were calculated using the solute activities in the aqueous leaching solutions that had reacted for 28 days. The corresponding exchangeable cation occupancies were derived from the inventory of exchangeable cations adjusted for the quantities of exchangeable cations extracted during the aqueous leaching. It was noted that the calcium/magnesium activity ratio of the aqueous leachates decreased with leaching time until, by 28 days, it reached 1.35, the ratio for equilibrium between calcite and dolomite. From this ratio and the exchangeable calcium and magnesium populations the calcium/magnesium selectivity coefficient was calculated.

Ratios of dissolved cations were calculated from the selectivity coefficients and in situ exchangeable cation populations. The total cation content was calculated from the equation for solution electroneutrality:

$$
m_{N a}+m_{K}+2 m_{C a}+2 m_{M g}=m_{C l}+2 m_{\text {Sulphate }}
$$

This equation is only approximate as it does not include minor species such as carbonate anions and minor metals.

In terms of Gibbs' Phase Rule, the system treated by Bradbury and Baeyens has 10 components: chloride, sulphate, carbonate, sodium, potassium, calcium, magnesium, fluoride, silica and $\mathrm{pH}\left(\mathrm{H}^{+}\right)$. Two of these, chloride and sulphate, were treated as free components and their concentrations were specified in the input. Seven reactive phases were considered: calcite equilibrium, the solution itself (corresponding to the electroneutrality constraint), exchangeable $\mathrm{KX}$, exchangeable $\mathrm{CaX}_{2}$, dolomite equilibrium, fluorite equilibrium, and quartz (chalcedony) equilibrium. One degree of freedom remained. This was accounted for by specifying the $\mathrm{PCO}_{2}$.

The chloride and sulphate concentrations were fixed at the values calculated from aqueous leaching of the core and the assumed porosity. The $\mathrm{PCO}_{2}$ was fixed at $10^{-2}$ bars, a value chosen by expert judgment and supported by work of Hutcheon and Abercrombie (1990) and Coudrain-Ribstein and Gouze (1993). These authors proposed that the $\mathrm{PCO}_{2}$ of waters in deep sedimentary basins could be explained by the reaction:

$$
5 \text { dolomite }+ \text { kaolinite }+ \text { quartz }+\mathrm{H}_{2} \mathrm{O}=\text { Mg-chlorite }+5 \text { calcite }+\mathrm{CO}_{2}
$$

Using the thermodynamic data of Michard (1983), Coudrain-Ribstein and Gouze (1993) modelled this reaction at temperatures from 30 to $150^{\circ} \mathrm{C}$ and compared the results with values measured on surface and borehole-sampled ground waters at temperatures from about 10 to $200^{\circ} \mathrm{C}$. At low temperatures (c. $10-30$ 
${ }^{\circ} \mathrm{C}$ ) the modelled $\mathrm{PCO}_{2}$ values were about $10^{-2}$ bars. With the $\mathrm{PCO}_{2}$ fixed at this value the system as described by Bradbury and Baeyens was fully specified and could be modelled.

To reach their final water composition, Bradbury and Baeyens adjusted several parameters to optimize agreement between the modelled and measured exchangeable cation populations. Lowering the $\mathrm{pH}$ increased calcite and dolomite solubilities and so increased the dissolved and exchangeable calcium and magnesium populations. The dissolved potassium concentration was chosen to match the measured exchangeable potassium population and sodium was adjusted so that the full solution, now including carbonate species, silica, alumina and fluoride, would be charge balanced.

The compositions calculated by Bradbury and Baeyens at assumed anion-bearing porosities of 10, 12 and $14 \%$ are illustrated in a Schoeller diagram in Figure 2. The composition of water samples taken from boreholes discussed above are also shown. The PC-C and BWS-A1 boreholes have the highest chloride contents ( 0.33 and $0.28 \mathrm{~mol} / \mathrm{L}(\mathrm{M})$, respectively) which correspond to Bradbury and Baeyens values calculated at an assumed porosity of about $10 \%(0.31 \mathrm{M}$ chloride). There is general agreement between the composition derived by Bradbury and Baeyens and that of the high-salinity measured waters, which is as it should be considering that the core sample they characterized was from the BWSA-1 borehole. The modelled potassium is considerably higher than the measured value, as is the modelled sulphate. The modelled calcium/magnesium ratio is greater than one while the ratio measured in water samples of similar salinity is less than one. The modelled alkalinity values agree with those of the BWS-A1 borehole but are lower than the values measured in the PC-C borehole of similar salinity and in the two lower-salinity samples.

\subsubsection{Models calibrated against analysed pore-water chemistry}

The modelling that followed the work of Bradbury and Baeyens was based on water samples collected from boreholes in the Mont Terri underground research laboratory and on exchangeable cation populations and selectivity coefficients measured on core samples across the entire section. The geochemical investigations at Mont Terri through 2001 are described in detail by Pearson et al. (2003 Annexes).

In the modelling of Pearson et al. (2003), chloride, bromide and, in most cases, sulphate were treated as free solutes in modelling the Mont Terri pore water. Chloride concentrations were fixed and the bromide and sulphate concentrations were chosen to correspond to their seawater ratios with the fixed chloride content. Because celestite $\left(\mathrm{SrSO}_{4}\right)$ appeared to be saturated in samples from the most saline boreholes (PC-C, BWSA1), the effect of treating sulphate as a solute controlled by celestite equilibrium was also examined.

The modelling performed on the borehole and squeezed samples collected during the first four years of Mont Terri underground research laboratory operation $(1997-2001)$ is described in detail by Pearson et al. (2003, 
Chapter 5). The modelling attempted to reproduce the measured properties of the water samples using mineral equilibria and cation exchange reactions. This modelling will be described in the context of other models that have appeared in the literature for pore-water in clay rocks.

Table 2 illustrates the correspondence between pore water chemical properties and constraints on them as represented in a number of pore water equilibrium models. The properties include the concentrations of all major and a few minor solutes as well as the $\mathrm{pH}$ and, in some cases, the redox potential of the solution. The constraints are mineral equilibria, cation exchange, fixed concentrations of free solutes and solution electroneutrality. In addition to models applied to Mont Terri waters, models described in the literature using different approaches to simulate pore waters in other systems are also included in Table 2.

\subsubsection{Models including feldspars}

Although the Bradbury and Baeyens (1998) and later models of Mont Terri pore waters include cation exchange, several models have been proposed for ground and pore waters from other locations in which feldspar equilibria were used instead of cation exchange. These are briefly discussed here because of their relevance to the broader question of the applicability of silicate mineral equilibria to the chemistry of lowtemperature waters.

The first of these models is that used by Coudrain-Ribstein and Gouze (1993) to calculate $\mathrm{PCO}_{2}$ values as functions of temperature in the Dogger of the Paris basin. The $\mathrm{PCO}_{2}$ value at $30^{\circ} \mathrm{C}$ from this modelling was used in the calculations of Bradbury and Baeyens. The $\mathrm{PCO}_{2}$ was considered to be controlled by reaction (4), above, but in order to model this reaction, it was necessary to consider the full chemistry of the pore water. The first column of Table 2 illustrates the modelling scheme used. Chloride was considered a free anion and fixed at its average concentration in their ground-water samples. Sulphate concentrations were linked to equilibrium with anhydrite $\left(\mathrm{CaSO}_{4}\right)$, and sodium, potassium, calcium and magnesium to equilibrium with albite $\left(\mathrm{NaAlSi}_{3} \mathrm{O}_{8}\right)$, K-feldspar or microcline $\left(\mathrm{KAlSi}_{3} \mathrm{O}_{8}\right)$, calcite $\left(\mathrm{CaCO}_{3}\right)$, and $\mathrm{Mg}$-chlorite $\left(\mathrm{Mg}_{3} \mathrm{Al}_{2} \mathrm{Si}_{3} \mathrm{O}_{10}(\mathrm{OH})_{8}\right)$, respectively. Total carbonate was associated with dolomite $\left(\mathrm{CaMg}\left(\mathrm{CO}_{3}\right)_{2}\right)$ and the $\mathrm{pH}$ with solution electroneutrality. The minor species silica, fluoride and aluminium were identified with fluorite $\left(\mathrm{CaF}_{2}\right)$, chalcedony $\left(\mathrm{SiO}_{2}\right)$ and kaolinite $\left(\mathrm{Al}_{2} \mathrm{Si}_{2} \mathrm{O}_{5}(\mathrm{OH})_{4}\right)$ equilibria. No redox calculations nor concentrations of redox-sensitive elements were included in this modelling. The thermodynamic data used are shown in Tab 2 of Coudrain-Ribstein and Gouze (1993) and were principally those of Michard (1983), with the dolomite equilibrium constant increased by $1.2 \log$ units to represent disordered dolomite.

Calculations were made at temperatures from 30 to $180^{\circ} \mathrm{C}$. and reasonably well reproduced the water chemistry and $\mathrm{PCO}_{2}$ values measured in waters from the Dogger aquifer of the Paris Basin and $\mathrm{PCO}_{2}$ values from other groundwater and geothermal systems (Coudrain-Ribstein and Gouze, 1993, Figure 5). Modelling 
with two other sets of mineral constraints was also undertaken. With laumontite $\left(\mathrm{CaAl}_{2} \mathrm{SiO}_{12} \cdot 4 \mathrm{H}_{2} \mathrm{O}\right)$ in place of $\mathrm{Mg}$-chlorite, the calculated $\mathrm{PCO}_{2}$ values were considerably below the measured values at all temperatures. With illite $\left(\mathrm{K}_{0.6} \mathrm{Mg}_{0.25} \mathrm{Al}_{2.3} \mathrm{Si}_{3.5} \mathrm{O}_{10}(\mathrm{OH})_{2}\right)$ replacing $\mathrm{Mg}$-chlorite, $\mathrm{PCO}_{2}$ values agreed with those from Paris Basin samples, all of which were between about 45 and $80^{\circ} \mathrm{C}$, but were far below values measured in higher-temperature waters.

The second model was developed by Beaucaire et al. (2000) to explore controls on the chemistry of pore water from the Boom Clay at the Mol URL and of a more chloride-rich water from the Rupelian aquifer, which underlies the Boom Clay. The second column in Table 2 describes the modelling scheme. The chloride and total carbonate contents were fixed at values typical of those of water samples from the two formations. The cations modelled were silica, aluminium, sodium, potassium, calcium and magnesium. These were associated with the minerals chalcedony, kaolinite, albite, microcline, calcite and dolomite. The $\mathrm{pH}$ was associated with solution electroneutrality. With the fixed total carbonate and modelled $\mathrm{pH}$ values, the alkalinities could also be calculated for comparison with the measured values.

Beaucaire et al. (2000 Table 4) compare thermodynamic data on the minerals and selected aqueous species used in their model with values given in the data compilations of Michard (1983) and Bowers et al. (1984), and in the SUPCRT database (Johnson et al. 1992; http:/geopig.asu.edu/ ) and the database for the aqueous modelling program MINTEQ. In their modelling, Beaucaire et al. (2000) use principally mineral data from Michard (1983) except for albite and microcline. Their values for the feldspars are different from those in any of the data sets. They were chosen so that they led to a $\mathrm{a}_{\mathrm{Na}^{+}} / \mathrm{a}_{\mathrm{K}^{+}}$ratio like those observed in pore waters and aquifer waters from the units being modelled.

Beaucaire et al. (2000) discuss the inclusion of Mg-chlorite in the models of Hutcheon and Abercrombie (1990) and of Coudrain-Ribstein and Gouze (1993) but point out that the stability constants for this mineral in the databases they considered range from -16.16 (Michard) to -22.57 (Bowers et al.). $\mathrm{PCO}_{2}$ values calculated using these values are -1.87 and $-3.11 \log$ bars, respectively. Although the former value is consistent with those of samples from the Rupelian aquifer, Beaucaire et al. choose not to include Mgchlorite in their modelling but instead specified total carbonate and associate magnesium concentrations with dolomite equilibrium.

Beaucaire et al. (2000) also discuss the exclusion of clay minerals from their modelling despite the fact they make up more than $50 \%$ of the Boom Clay. They felt unable to include clay-mineral equilibrium because it was not clear whether to treat clays as phases of defined compositions or as solid solutions. They also considered treating the clays as cation exchange substrates. In this case, if exchange selectivity coefficients and in situ cation populations were known, ratios of exchangeable cations in solution could have been calculated as was done by Bradbury and Baeyens (1998). Sufficient data were available for Beaucaire et al. 
(2000) to calculate magnesium and calcium concentrations. These were within an order of magnitude of measured values, but did not agree nearly as well with them as those calculated using the equilibrium model described in Table 2. These authors also felt that because the cation exchange model is dependent on the quantities of solids present (i.e., the in situ populations of the exchangeable cations), it is not formally as well constrained a model for water chemistry as one based on equilibrium with pure phases like the feldspars.

Gaucher et al. (2009) consider feldspar equilibrium in discussing their model for COx pore-water chemistry. Their Figure 6 shows that the exchangeable sodium and potassium contents measured in COx samples are inconsistent with feldspar equilibrium in this formation. Figure 3 compares $\log \left(\mathrm{a}^{\mathrm{Na}^{+}} / \mathrm{a}_{\mathrm{K}^{+}}\right)$values of samples from the Mont Terri boreholes BWS-A3, BWS-A1, and PC-C with values corresponding to equilibria with feldspars with the properties given in various thermodynamic databases and used by Beaucaire et al. (2000). This illustrates that feldspar equilibrium is inconsistent with the chemistry of Mont Terri pore water as it is with that of COx pore water.

It is of interest to explore why feldspar equilibrium does not prevail in Opalinus clay and COx pore waters while it is apparently is important in the waters modelled by Coudrain-Ribstein and Gouze (1993). A possible explanation can be found in the work of Stefansson and Arnorsson (2000) who examined the saturation states of albite and microcline in a number of natural waters with temperatures ranging to over $300^{\circ} \mathrm{C}$. They found reasonable agreement between measured and calculated sodium/potassium ratios for waters down to temperatures of about $50^{\circ} \mathrm{C}$. In lower temperature waters, though, the measured sodium/potassium ratios, like those in Figure 3, were lower than the calculated values (Stefansson and Arnorsson (2000) figure 6). They concluded that feldspar equilibrium was not common at temperatures below about $50^{\circ} \mathrm{C}$. Because the water temperature at Mont Terri is about $13^{\circ} \mathrm{C}$ and that of the COx samples about $25^{\circ} \mathrm{C}$, below the lowest temperature at which Stefansson and Arnorsson (2000) found feldspar equilibrium, the lack of feldspar equilibrium in samples from these sites is not surprising

\subsubsection{Modelling with cation exchange}

The third column in Table 2 summarizes the modelling of Bradbury and Baeyens (1998) and of Bradbury et al. (1997-1998) described above. Note that in this model and those that follow in Table 2, cation exchange rather than feldspar equilibrium is used.

The fourth column summarizes the modelling undertaken by Pearson et al. (2003) as part of their compilation and interpretation of pore water chemical data collected at the Mont Terri through 2001. For several reasons this modelling could be considerably more extensive than previous modelling. First, 
analyses of additional pore-water solutes were available including trace elements and redox-sensitive species such as iron, manganese and uranium. This made it possible to include redox reactions in the modelling. Second, field measurements were made of ephemeral properties of the borehole water such as its $\mathrm{pH}$ and Ptelectrode potentials. Finally, both laboratory and field measurements of the gas contents of pore water were also made which provided additional definition of the dissolved carbonate system.

Pearson et al. (2003, Section 5.4.1) describe the 2003 modelling approach in detail as it was applied to waters from the BWSA-1 and BWSA-3 boreholes. It was carried out using PHREEQC (Parkhurst and Appelo 1999) with the Nagra/PSI thermodynamic database (Hummel et al. 2002) and can be exemplified by the modelling of the BWSA-3 borehole waters. The measured composition of the borehole waters is shown in Table 1 and Figure 2. BWSA-3 water is also illustrated in Figure 4 where it is compared with results of various models.

The average chloride content of the BWSA-3 borehole is $0.12 \mathrm{~mol} / \mathrm{kg}_{\mathrm{w}}$. This corresponds to $23 \%$ of the chloride content of seawater. A water containing $23 \%$ of the solutes in sea water is shown in Figure 4 and was the starting water for the modelling. The differences between the pore water composition and seawater shown in that figure are as expected from diagenetic reactions. The aragonite and calcite originally precipitated from seawater contain a certain amount of magnesium and strontium. Recrystallization of these early carbonates together with dolomitization increases the relative strontium content of the pore water and shifts the calcium/magnesium ratio from its initially low value to a ratio slightly greater than one.

The nominal constraints on the 2003 modelling are those listed in column 4 of Table 2. These consisted of cation exchange for sodium/calcium, sodium/potassium and sodium/strontium ratios and saturation with respect to calcite, dolomite, quartz and kaolinite. Solution electroneutrality was also a constraint and was associated with $\mathrm{pH}$. The $\mathrm{PCO}_{2}$ value establishes total carbonate content and alkalinity. $\mathrm{PCO}_{2}$ was fixed at $10^{-2.2}$ bars which was an average of values calculated from $\mathrm{pH}$ and alkalinity measurements of the borehole samples. The nominal constraints on redox-sensitive solutes included control of the redox state of the solution by the S(VI)/S(-II) couple. S(VI) corresponds to the sulphate concentration of the solution, and S(II) is based on pyrite solubility. To calculate pyrite solubility requires an iron concentration. In the nominal case, this was calculated by specifying saturation with siderite, a mineral present at about 2 weight percent throughout the Opalinus Clay (Pearson et al. 2003 Annex 9).

Measured and modelled major solute compositions are shown in Figure 4. The results of modelling with several sets of constraints are included, selected from a more extensive group shown in Table 5.10 of Pearson et al. (2003).

With a few exceptions, the nominal model (designated A3-A in Figure 4 and Pearson et al. 2003) is 
generally consistent with the measured composition. The modelled potassium is considerably higher than that measured. Both magnesium and calcium are somewhat lower than the measured values. The modelled strontium is lower than the measured value. The sulphate and alkalinity are also lower than the measured values.

The effects of variations on some of the constraints on the nominal model are also shown in Figure 4:

- Variation A3-B was an attempt to match the modelled potassium concentration to the measured values. Following equation 2 this could have been done by raising the selectivity coefficient or by lowering the exchangeable potassium content. The latter alternative was chosen and the exchangeable potassium population was arbitrarily reduced by a factor of four bringing the modelled potassium concentration into agreement with the measured value. As shown in section 2.2.2, however, the wiser choice would have been to raise the selectivity coefficient.

- In all variations but A3-D, dolomite equilibrium is specified fixing the dissolved magnesium concentration and, consequently, the exchangeable magnesium population. In variation A3-D, dolomite saturation is not specified so the magnesium concentration is established by the exchangeable magnesium population which is specified in the input. The resulting dissolved magnesium concentration is higher and is closer to the measured value than in the nominal case but the calcium/magnesium ratio is less than one while that measured in BWS-A3 borehole water is greater than one.

- In variation A3-E, dolomite saturation is enforced and there is no initial $\mathrm{PCO}_{2}$ constraint in the modelling so the total carbonate content is established by dolomite equilibrium. The resulting modelled magnesium and calcium contents are nearly the same as in the nominal case but the alkalinity is considerably below both the measured value and those modelled in all other variations. The $\mathrm{PCO}_{2}$ calculated in this variation is $-3.8 \log$ bars, considerably below the measured $-2.2 \log$ bars. The calculated $\mathrm{pH}$ is 8.2 , well above the average measure value of 7.4

- In variation A3-C, the sulphate concentration is established by celestite saturation rather than being fixed in the input. This produces a sulphate concentration about $30 \%$ higher than the measured value and about $50 \%$ higher than the sulphate concentration input to the other model variations, which corresponded to the sulphate/chloride ratio of sea water. The higher sulphate requires higher cation concentrations to maintain solution electroneutrality. This raises the magnesium, calcium and strontium concentrations to values closer to those of the pore water than in the nominal modelling scenario. The fact that the BWSA-3 pore water sulphate is higher than that corresponding to a seawater sulphate/chloride ratio is also evident in Figure 1. As discussed in section 2.2.1, BWS-A3 borehole water is undersaturated with respect to celestite, assuming the solution concentrations and the activity corrections and celestite equilibrium constant in the database are correct. Thus, while variation $\mathrm{A} 3-\mathrm{C}$ reproduces the measured cation composition better than the nominal scenario or any 
of the other variations, it still does not completely represent formation controls on the pore water chemistry.

\subsubsection{Redox modelling}

Figure 5 compares the measured concentrations of the redox-sensitive elements uranium, iron and manganese to those modelled with different sets of constraints. In all variations, uranium is established by uraninite $\left(\mathrm{UO}_{2}\right)$ saturation. Although this mineral has not been observed in Mont Terri rock, uranium concentrations in many ground waters are consistent with equilibrium with it. At uranium concentrations in the range of those measured, dissolved uranium is dominantly in an oxidized redox state, principally U(VI) (Langmuir 1997). Thus, the different modelled uranium concentrations represent differences in the redox potentials produced by several redox-controlling reactions tested.

In all variations manganese concentrations are associated with rhodochrosite $\left(\mathrm{MnCO}_{3}\right)$ saturation. No pure manganese minerals have been identified in the formation but $\mathrm{Mn}(\mathrm{II})$ is commonly present in carbonate minerals such as dolomite or ankerite (Deer, Howie and Zussman 1992). The fact that the manganese concentrations of all model variations are nearly the same indicates that manganese is present as $\mathrm{Mn}$ (II) over the entire range of redox conditions tested. The fact that the modelled and measured concentrations are similar suggests that manganese control by a carbonate mineral is a reasonable hypothesis.

Three minerals were tested as controls on dissolved iron concentrations: siderite $\left(\mathrm{FeCO}_{3}\right)$, goethite $(\mathrm{FeOOH})$ and micro-crystalline ferric hydroxide $\left(\mathrm{Fe}(\mathrm{OH})_{3}\right)$. Siderite is present in the clays at Mont Terri. The ferric solids have not been specifically identified there but are common phases in iron-bearing systems.

In the nominal scenario, A3-A, the redox state is specified by the sulphate/sulphide couple. Sulphate is fixed at the seawater sulphate/chloride ratio in the scenarios shown in Figure 5, and sulphide by pyrite saturation. Three alternate scenarios differ in the equilibria controlling their dissolved iron concentrations. Goethite control (A3-F) leads to the lowest iron and so to the highest sulphide concentration at pyrite saturation. This, in turn, produces the lowest redox potential and, consequently, the lowest dissolved uranium concentration. Micro-crystalline $\mathrm{Fe}(\mathrm{OH})_{3}$ control (A3-G) leads to the highest iron and, consequently, to the lowest sulphide concentration and highest redox potential. This, in turn, produces the highest uranium concentration. In all other scenarios, siderite control is used leading to intermediate iron concentrations.

In two of the scenarios, redox was established by the $\mathrm{Fe}(\mathrm{III}) / \mathrm{Fe}(\mathrm{II})$ couple with the $\mathrm{Fe}$ (II) concentration controlled by siderite. In variation A3-I, $\mathrm{Fe}(\mathrm{III})$ is controlled by micro-crystalline $\mathrm{Fe}(\mathrm{OH})_{3}$ and in variation A3-H by goethite. The former leads to a relatively high Fe(III) which produces a high redox potential and a uranium concentration far above the measured value. The Fe(III) concentration in equilibrium with goethite is low, leading to a sulphide concentration at pyrite saturation high enough that sulphide rather than sulphate 
is the dominant sulphur species. This variation is also shown in Figure 4 illustrating a modelled sulphate concentration far below that measured. The fact that neither a goethite nor a micro-crystalline $\mathrm{Fe}(\mathrm{OH})_{3}$ model leads to solute concentrations resembling those measured is consistent with the fact that neither phase has been observed in samples which have been preserved from oxidation.

\subsubsection{Summary of shortcomings of early modelling}

The 2003 modelling provided insights into the details of processes controlling the pore water chemistry at Mont Terri and successfully reproduced many of the measured properties of the pore water. However several questions remained including:

- While it is clear that the water is moderately reducing, with $\mathrm{Mn}(\mathrm{II}), \mathrm{Fe}(\mathrm{II}), \mathrm{U}(\mathrm{VI})$ and $\mathrm{S}(\mathrm{VI})$ the dominant redox states of the solute species of their respective elements, the specific minerals or solid solutions that control the concentrations of redox sensitive species are not known;

- The relationship between strontium and sulphate concentrations and celestite equilibrium in the less saline waters;

- The inability to model the dissolved potassium concentration with the cation exchange properties measured;

- $\quad$ The lack of consistency between measured magnesium and calcium concentrations and ratios, and those modelled using sodium/magnesium exchange and dolomite saturation;

- $\quad$ An inability to reproduce the measured carbonate chemistry and $\mathrm{pH}$ of the pore water using mineralwater reactions alone. Successful modelling of carbonate and $\mathrm{pH}$ required that the $\mathrm{PCO}_{2}$ or some other carbonate property such as total dissolved carbonate be specified in the model input.

To further clarify the reactions influencing the redox state will require additional petrographic amd mineralogical study of the formation before the modelling can be improved. As this is not yet available, only the last four of these questions are addressed in the more recent modelling discussed here.

\subsection{Recent Advances}

Advances in modelling have been made possible by improvements in the understanding of cation exchange processes, and by the availability of samples from the PC-C borehole and of additional samples from the BWSA series boreholes. A second set of samples from the BWS-A series boreholes was taken roughly yearly from May 2003 through March 2006. The analyses of these samples are given In the electronic annex of Wersin et al. (This issue) and are included in the averages in Table 1. Water samples and in situ measurements of $\mathrm{pH}$ and gas compositions were collected from the PC-C borehole from August 2004 through December 2007. These measurements are described and the water chemical data are given by Vinsot et al. (2008) and the averages are included in Table 2. The recent modelling is described as it has 
been applied both at Mont Terri (Wersin et al. 2009) and to water from Callovo-Oxfordian (COx) sediments from the underground research laboratory operated by Andra at Bure (Gaucher et al. 2006, 2009).

The recent modelling has examined the controls on the strontium and sulphate concentrations and on the dissolved potassium concentrations. It has also explored dependencies among calcium and magnesium concentrations, carbonate mineral and cation exchange equilibria, and measured $\mathrm{pH}$ and $\mathrm{PCO}_{2}$ values. While $\mathrm{pH}$ and $\mathrm{PCO}_{2}$ are certainly related through equilibria in the carbonate system, their measurement on borehole water samples and on core samples are difficult and the results may not be consistent. Finally, the modelling addressed the extent to which $\mathrm{pH}$ and $\mathrm{PCO}_{2}$ values could be modelled using silicate mineral equilibria like those proposed by Hutcheon and Abercrombie (1990) and used by Coudrain-Ribstein and Gouze (1993).

The modeling described by Pearson et al. (2003) was done using PHREEQC (Parkhurst and Appelo 1999) and the Nagra/PSI thermochemical database (Hummel et al. 2002). The modeling discussed in the remainder of this paper was also done using PHREEQC but with the BRGM (THERMODDEM) database (Blanc et al. 2007). Results of modeling using the two databases are closely similar but the BRGM database includes a number of alumino-silicate minerals not present in the Nagra/PSI database..

\subsubsection{Strontium and sulphate}

In most of the 2003 modelling of samples from the BWSA series of boreholes, sulphate was treated as a free solute with concentrations generally fixed at the sulphate to chloride ratio of normal seawater. Equilibrium with celestite was included in variation $\mathrm{A} 3-\mathrm{C}$ of the modelling, in which case sulphate was a controlled solute (Table 2, Figure 4).

Gaucher et al. (2009) concluded that water in the COx is saturated with celestite, which is present throughout the section studied. With strontium fixed by cation exchange, sulphate concentrations are determined by celestite equilibrium.

Pore waters from the BW-SA1 and PC-C boreholes are saturated with respect to celestite, while those from the BWSA-2 and BWSA-3 are undersaturated (Pearson et al. 2003; Wersin et al. 2009). Celestite is reported in two core samples with pore-water chloride contents similar to that of the BWSA-1 borehole water (Pearson et al. 2003 Sect. A9.4). Celestite has not been reported from lower-chloride parts of the system, but no systematic search for it has been conducted so it could be present in small amounts. Celestite is also not reported from the PC borehole overcore, but again, no systematic search for it has been conducted (Koroleva et al. This issue). Wersin et al. (This issue, Sect 3.5) point out that while the dissolved strontium concentrations of the borehole water remained relatively constant throughout the PC experiment, celestite 
became increasingly undersaturated as the dissolved sulphate concentration decreased. This is consistent with the lack of evidence for celestite in the core.

No gypsum was observed in Mont Terri rocks except for small amounts on fracture surfaces of samples taken from or near the tunnel wall where partial desaturation and oxidation may well have occurred. The probable explanation for the gypsum oversaturation noted by Bradbury and Baeyens in their modelling is that pyrite oxidation took place in the core before or during leaching producing higher sulphate contents in aqueous leachates. Modelling to gypsum saturation would lead to the higher modelled-than-measured sulphate contents evident in Figure 2.

Figure 1 shows that the sulphate/chloride ratios of the BWSA-2 and BWSA-3 waters are above that of seawater. These samples are undersaturated with celestite so the sulphate they contain above that corresponding to the seawater sulphate/chloride ratio could have come from celestite dissolution. Modelling the BWSA-3 water at celestite saturation led to a dissolved sulphate concentration above the measured value (Scenario A3-C, Figure 4). If the sulphate above that corresponding to the seawater ratio came from celestite dissolution, there could not have been sufficient celestite originally present to bring the waters to saturation and celestite should be absent from the formation where celestite-undersaturated waters are found.

As mentioned above, the distribution of pore-water salinity at Mont Terri can be explained as the result of diffusion of salts from an initial pore water of seawater composition to fresh-water bounding aquifers. Because of its size and charge, sulphate diffuses more slowly than chloride (e. g. Appelo et al. 2008 Tab 3). Thus, if the sulphate concentration was determined only by diffusion, the sulphate/chloride ratios of the pore waters increase above that of sea water as the chloride content decreases. This is not the case for samples from the most saline boreholes (PC-C ansd BWSA-1), for which pyrite oxidation can be confidently ruled out, so some reaction must be occurring that decreases sulphate relative to chloride. Waters from these boreholes are saturated with celestite so most likely reaction is celestite precipitation. As diffusion proceeds and the salinity decreases so will the strontiun content which is controlled by cation exchange. At some point strontium will drop below the level requires for celestite precipitation and the sulphate/chloride ratio will increase as the chloride content decreases. Waters from the BWS-A1 and PC-C boreholes with highest chloride contents are saturated with respect to celestite. Water from the BWSA-1 and BWSA-3 boreholes have lower chloride contents, are undersaturated with respect to this mineral and have somewhat higher sulphate/chloride ratios.

If the Opalinus clay was to be modelled based on rock properties alone, the presence of strontium as an exchanged cation and of celestite in at least a few core samples would indicate that sulphate should be modelled as controlled by celestite saturation. Assuming correct strontium exchange properties, this would lead to correct sulphate concentrations for high chloride waters (Table 5) and to sulphate concentrations that 
are high by about $30 \%$ in waters with chloride contents as low as BWSA-3 (Figure 5; Pearson et al, 2003 Table5.10).

\subsubsection{Potassium concentration control}

In the early modelling of Bradbury and Baeyens (1998) and Pearson et al. (2003), potassium concentrations were based on sodium/potassium exchange using measured, exchangeable potassium populations and sodium/potassium selectivity coefficients measured on Mont Terri core samples or from the literature (Tables 3 and 4). The measured potassium concentrations were considerably below those calculated (Figures 2 and 4) but could be reproduced by modelling with an exchangeable potassium concentration lower by a factor of four than the measured value (Figure 4, model A3-B). This arbitrary correction was an unsatisfactory solution so laboratory work was undertaken to improve understanding of potassium and other cation exchange.

Selectivity coefficients measured on and used for modelling Mont Terri samples are shown in Table 4. In the earlier modelling, a single exchange site was considered with selectivity coefficients that were independent of the exchangeable cation populations. Laboratory studies on the clay-size fraction of a core sample from Mont Terri showed that the distribution of potassium could better be described by a model that included two exchange sites (Pearson et al. 2003 Section A3.6). However, these results were not taken into account in the modelling described in that report.

Multi-site exchange models proved to be very efficient in predicting the caesium sorption capacity of illitecontaining materials by cation exchange reactions (Poinssot et al., 1999; Bradbury and Baeyens, 2000; Steefel et al., 2003). Such models include competition between $\mathrm{K}^{+}$and $\mathrm{Cs}^{+}$for sorption on the same sites. In particular, both $\mathrm{K}^{+}$and $\mathrm{Cs}^{+}$were shown to sorb on high and low affinity sites where the high affinity sites are less numerous than the low affinity sites. In situ fractional exchangeable potassium occupancies of Opalinus Clay samples measured by several laboratories ranged from 0.05 to 0.10 (Pearson et al. 2003 Table A3.12). Under these conditions, high affinity sites prevail over low affinity sites explaining why high selectivity coefficients are needed for $\mathrm{Na} / \mathrm{K}$ exchange reaction. More recently, Tournassat et al. (2007, $2008,2009)$ describe cation exchange on illite and on smectite and mixed-layer illite/smectite minerals based on their own and on literature data. For illite they tested two models, a two-site model with constant Gaines-Thomas selectivity coefficients, and a one-site model which included surface species activity coefficients. The latter led to selectivity coefficients that varied with the exchangeable cation population.

Figure 6 compares sodium/potassium selectivity coefficients measured on the $<2$ micron fraction of Opalinus Clay and on illite type Imt-2 from the Source Clay collection with values from the one-site sodium/potassium model of Tournassat et al. (2009). Extrapolation of the curves in Figure 6 to potassium 
occupancies from 0.05 to 0.1 indicates selectivity coefficients of about 0.9 or greater for Mont Terri samples and from about 1.1 to 1.2 for Imt-2. A more complete model that considers the effects of exchanged divalent cations on the sodium/potassium selectivity coefficient has also been developed by Tournassat et al. (2009). Its application to an exchanger with the measured cation population shown in Table 3 led to a selectivity coefficient of 1.0. The model of Bradbury and Baeyens (2000) results in an even higher $\log \mathrm{K}_{\mathrm{G}-\mathrm{T}}^{\mathrm{Na} / \mathrm{K}}$ value of 1.5 as the potassium occupancy becomes very small, but this model does not predict the decrease in the selectivity coefficient as the potassium occupancy exceeds about 0.6 (Figure 6).

Figure 3 shows $\log \left(\mathrm{Na}^{+} / \mathrm{a}_{\mathrm{K}^{+}}\right)$for samples of the PC-C, BWS-A1, and BWS-A3 boreholes. Two samples have values below 2.0 due to exceptionally high reported potassium contents. It is assumed these are due to analytical artefacts and the samples are excluded from further consideration. The figure shows a pattern of increasing sodium/potassium ratios for the BWS-A1 and BWS-A3 samples taken during the first two years and for all the PC-C samples. Ratios of BWS-A1 and BWS-A3 samples taken from 2003 to 2006 vary somewhat but there is no pattern of change with time and these ratios are all in the range of those of the earlier samples. The ratios of samples from all three boreholes overlap within one standard deviation. The mean and two standard deviation values of all but the two outlying $\log \left(\mathrm{a}_{\mathrm{Na}^{+}} / \mathrm{a}_{\mathrm{K}^{+}}\right)$values is $2.2 \pm 0.2$.

Equation (2) for the sodium/potassium selectivity coefficient can be written as:

$$
\log \mathrm{K} \mathrm{G}-\mathrm{T} / \mathrm{K}=\log \left(\mathrm{a}_{\mathrm{Na}^{+}} / \mathrm{a}_{\mathrm{K}^{+}}\right)+\log \left(\mathrm{E}_{\mathrm{KX}} / \mathrm{E}_{\mathrm{NaX}}\right)
$$

where $\log \left(\mathrm{E}_{\mathrm{KX}} / \mathrm{E}_{\mathrm{NaX}}\right)$ is the ratio of the exchanged ion population in equivalents and $\log \mathrm{K}_{\mathrm{G}-\mathrm{T}}^{\mathrm{Na} / \mathrm{K}}$ is the $\log$ of the Gaines-Thomas selectivity coefficient.

Exchangeable sodium and potassium populations measured on a number of samples from Mont Terri by several laboratories are given by Pearson et al. (2003 Tab 3.11 and 3.12) and are summarized in Table 3. From the measured values in this table the mean $\log \left(\mathrm{E}_{\mathrm{KX}} / \mathrm{E}_{\mathrm{NaX}}\right)$ value is $-0.89 \pm 0.10$. From equation (11), the $\log \mathrm{K}_{\mathrm{G}-\mathrm{T}}^{\mathrm{Na} / \mathrm{K}}$ value corresponding to this $\log \left(\mathrm{E}_{\mathrm{KX}} / \mathrm{E}_{\mathrm{NaX}}\right)$ and to the mean $\log \left(\mathrm{a}^{+} / \mathrm{a}_{\mathrm{K}^{+}}\right)$of $2.2 \pm 0.2$ from Figure 3 is $1.3 \pm 0.2$. 
Comparison with the values in Table 4 shows that this $\log \mathrm{K}_{\mathrm{G}-\mathrm{T}}^{\mathrm{Na} / \mathrm{K}}$ value is considerably above the values measured on Mont Terri samples and those used for the 2003 modelling, but overlaps the values measured on and used for modelling COx samples. It also overlaps the range of selectivity coefficients calculated for illite Imt-2 but is slightly above those calculated for Mont Terri with the model of Tournassat et al. (2009) and slightly below those calculated with the model of Bradbury and Baeyens (2000) as shown in Figure 6

As equation (11) shows, the measured $\log \left(\mathrm{a}^{\mathrm{Na}^{+}} / \mathrm{a}_{\mathrm{K}^{+}}\right)$value would be consistent with the lower $\log \mathrm{K}_{\mathrm{G}-\mathrm{T}}^{\mathrm{Na}} \mathrm{K}$ values used in the earlier modelling and proposed by Tournassat et al. (2009) for illite from the Opalinus Clay if the exchangeable potassium content of the Clay $\left(\log \left(\mathrm{E}_{\mathrm{KX}} / \mathrm{E}_{\mathrm{NaX}}\right)\right.$ ) was lower than the measured value used in the modelling. Scenario A3-B (Figure 4) showed that lowering the exchangeable potassium population by a factor of four would give the measured, dissolved potassium concentration. It seems unlikely that the measurement of exchangeable cation populations would be this much in error. Thus, the incorrect potassium concentrations in the earlier modelling must be attributed to the use of an incorrectly low value for $\log \mathrm{K}_{\mathrm{G}-\mathrm{T}}^{\mathrm{Na} / \mathrm{K}}$.

The recent work cited illustrates the improved understanding of sodium/potassium exchange since the earlier modelling. This results principally from the realization that sodium/potassium selectivity coefficients vary with the exchangeable potassium population and that the low potassium contents of the Mont Terri clays are associated with $\log \mathrm{K}$ values of 1.0 to 1.4 , higher than the values of around 0.7 found in the literature and used for the earlier modelling. The generic models developed by Tournassat et al. $(2007,2009)$ give an estimate for $\log \mathrm{K}_{\mathrm{G}-\mathrm{T}}^{\mathrm{Na} / \mathrm{K}}$ values that reduces the difference between modelled and measured potassium concentrations. The agreement is however not perfect. Using a predicted $\log \mathrm{K}$ value of 1 instead of a value of 1.3-1.4 (based on borehole pore water and core sample analyses) increases the calculated potassium concentration by a factor 2 to 3 . This problem is inherent to a generic model that is calibrated on a wide range of data obtained on materials similar to but not identical with site material. The model of Bradbury and Baeyens (2000) gives approximately the expected $\log \mathrm{K}_{\mathrm{G}-\mathrm{T}}^{\mathrm{Na}}$ value but is not able to describe laboratory data at higher potassium occupancies. Even though neither of these two modelling approaches gives perfect results, they demonstrate that changes in cation exchange selectivities with exchanger composition (as well as with the nature of material and perhaps the nature of the counter-ions and salinity, Baeyens and Bradbury, 2004) must be taken into account in predictive modelling. For this reason, a best independent measurement of selectivity coefficients value could be obtained by performing exchange experiments with an equilibrium solution having a composition similar to the pore water composition instead 
of a binary solution (e.g. Na-K) at low ionic strength (low ionic strength conditions are usually necessary in these experiments to reduce the error bands on the determination of selectivity coefficients values, see Tournassat et al., 2009). Gaucher et al. (2009) performed such experiments on COx clay fraction and showed that selectivity coefficient values given by generic predictive models were in quite good, although not perfect, agreement with values measured in these experiments (see table 3 of this reference). For the present work, these experiments were not performed but selectivity coefficients can be calculated from borehole water and core sample exchanger composition analyses, resulting in a $\log \mathrm{K}_{\mathrm{G}-\mathrm{T}}^{\mathrm{Na} / \mathrm{K}}$ value between 1.2 and 1.4. This last value is used in the following.

\subsubsection{Carbonate mineral equilibria and calcium/magnesium exchange}

Calcite is present in significant amounts (about 10 to 40\%) throughout the Opalinus Clay (Pearson et al. 2003 Table A9.3; Koroleva et al. this issue). Ground waters in calcite-bearing aquifers are generally saturated with respect to this mineral. Thus, calcite saturation is included in all of the models of Table 2 associated with calcium or carbonate concentrations.

However, modelling the chemistry of a number of Mont Terri borehole water samples leads to calcite oversaturation (Pearson et al. 2003 Annex A; Vinsot et al. 2008a). This may be attributable to the loss of $\mathrm{CO}_{2}$ from the samples before or during $\mathrm{pH}$ measurements, particularly those made in the laboratory (Pearson et al. 1978, 1989), and so does not contradict the assumption of calcite equilibrium.

In most of the models of Table 2, dolomite equilibrium was assumed. Whether this assumption is correct in Opalinus Clay pore water requires further consideration.

Calcite and dolomite dissolution are described by the reactions:

$$
\begin{gathered}
\mathrm{CaCO}_{3}+\mathrm{H}^{+} \leftrightarrow \mathrm{Ca}^{2+}+\mathrm{HCO}_{3}^{-} \\
\text {and } \mathrm{CaMg}\left(\mathrm{CO}_{3}\right)+2 \mathrm{H}^{+} \leftrightarrow \mathrm{Ca}^{2+}+\mathrm{Mg}^{2+}+2 \mathrm{HCO}_{3}^{-}
\end{gathered}
$$

Combining the $\log \mathrm{K}$ expressions for these reactions yields:

$$
\log \left(\mathrm{a}_{\mathrm{Ca}^{2+}} / \mathrm{a}_{\mathrm{Mg}^{2+}}\right)=2 \log \mathrm{K}_{\text {calcite }}-\log \mathrm{K}_{\text {dolomite }}
$$


Based on the $\log \mathrm{K}(25)$ values of 1.85 for calcite and 3.53 for dolomite in the BRGM database, $\log \left(\mathrm{a} \mathrm{aa}^{2+} / \mathrm{a}_{\mathrm{Mg}^{2+}}\right)$ at equilibrium with both minerals should be 0.16 at $25^{\circ} \mathrm{C}$. At $13^{\circ} \mathrm{C}$, the typical in situ temperature in the Mont Terri laboratory, the value should be 0.06 .

Figure 7 shows $\log \left(\mathrm{Ca}^{2+} / \mathrm{a}_{\mathrm{Mg}^{2+}}\right)$ values for Mont Terri borehole samples calculated at the temperatures at which they were collected. The range of values differs from borehole to borehole. The means and two standard deviation (SD) values calculated for samples from the several boreholes are: BWS-A3 $=0.04 \pm 0.04$, BWS-A $1=-0.04 \pm 0.03$ and PC-C. $=-0.09 \pm 0.02$. These ranges of the BWS-A1 and PC-C boreholes overlap at the two SD level, but the range of the BWS-A3 does not overlap with either of the other boreholes.

The value that $\log \left(\mathrm{Ca}^{2+} / \mathrm{a}_{\mathrm{Mg}^{2+}}\right)$ would have in water in equilibrium with both calcite and dolomite at $13^{\circ} \mathrm{C}$ is also shown in Figure 7. This value is within the range of values for BWS-A3 waters but differs by more than 2 SD from values for the other two boreholes. This suggests that although the measured ratios for BWS-A3 could be in equilibrium with dolomite, if the other boreholes are also in equilibrium with dolomite the mineral would have to have different thermodynamic properties to produce the pattern of $\log \left({ }^{\mathrm{Ca}^{2+}} / \mathrm{a}_{\mathrm{Mg}^{2+}}\right)$ values shown in Figure 7. Such a variation of mineral properties seems unlikely within a single formation at distances of less than $100 \mathrm{~m}$ and casts doubt on the hypothesis that the water chemistry throughout the formation is in equilibrium with dolomite.

Calcium and magnesium cation exchange is another possible control on pore-water chemistry. This exchange can be described by:

$$
\mathrm{Mg}^{2+}+\mathrm{CaX}_{2} \leftrightarrow \mathrm{Ca}^{2+}+\mathrm{MgX}_{2}
$$

The selectivity coefficient for this reaction is:

$$
\log \mathrm{K}_{\mathrm{G}-\mathrm{T}}^{\mathrm{Ca} / \mathrm{Mg}}=\log \left(\mathrm{a}_{\mathrm{Ca}^{2+}} / \mathrm{a}_{\mathrm{Mg}^{2+}}\right)+\log \left(\mathrm{E}_{\mathrm{MgX}_{2}} / \mathrm{E}_{\mathrm{CaX}_{2}}\right) .
$$

By combining equation 16 with equation 14, one can directly link the dolomite/calcite equilibrium to the $\mathrm{Ca} / \mathrm{Mg}$ occupancy ratio in the exchanger. Using this relationship, Tournassat et al. (2008) showed that this 
occupancy ratio is rather constant in the Callovian-Oxfordian formation at Bure and concluded that calcite and dolomite are at equilibrium with porewater composition in this formation. They could also conclude that, amongst the range of dolomite solubility products available in various database $(\sim 2.5, \sim 3.5$ or $\sim 4.1$ as a function of cristallinity), the value of $\sim 3.5$ derived from Hemingway and Robie (1994) was the most appropriate.

Measurements of the exchangeable cation populations of Mont Terri samples made by several laboratories are given in Pearson et al. (2003 Table A3.11) and summarized in Table 3. From the measured values in this table, the exchangeable magnesium to calcium ratio is $0.63 \pm 0.06$ with a mean $\log \left(\mathrm{E}_{\mathrm{MgX}_{2}} / \mathrm{E}_{\mathrm{CaX}}\right)$ value of $-0.20 \pm 0.04$

Values of $\log K_{G-T}^{\mathrm{Ca} / \mathrm{Mg}}$ measured on various Mont Terri samples by several laboratories are shown in Table 4. They range from -0.08 to -0.19 . A value of -0.20 was used in the 2003 modelling. The range of $\log \left(\mathrm{a}^{\mathrm{Ca}^{2+}} / \mathrm{a}_{\mathrm{Mg}^{2+}}\right)$ values calculated from these populations and selectivity coefficients using equation (16) is from -0.03 to 0.16 .

As shown in Figure 7, the $\log \left({ }^{\mathrm{a}^{2+}} / \mathrm{a}_{\mathrm{Mg}^{2+}}\right)$ values of samples from the PC-C, BWS-A1, and BWS-A3 boreholes range from about -0.11 to 0.07 . This range broadly overlaps that calculated from the exchangeable cations populations and selectivity coefficients, and supports the use of cation exchange as a control on magnesium concentrations in earlier modelling.

The question of why the measured ratios differ among the three boreholes is still present, however. One possibility is that the $\log \mathrm{K}_{\mathrm{G}-\mathrm{T}}^{\mathrm{Ca} / \mathrm{Mg}}$ or $\log \left(\mathrm{E}_{\mathrm{MgX}_{2}} / \mathrm{E}_{\mathrm{CaX}_{2}}\right)$ values vary across the formation. Measured values for these properties are given in Tables A3.12 and A3.13 of Pearson et al. (2003). There is no pattern

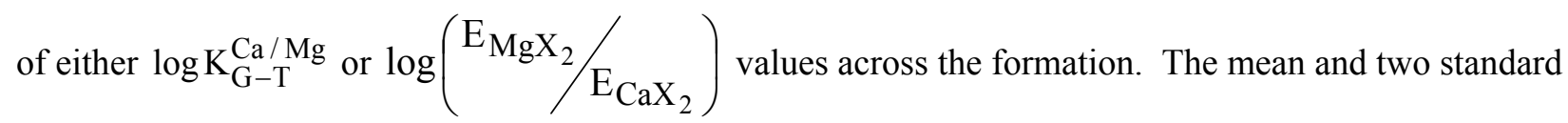
deviation values of the $\log \left(\mathrm{a}^{2}{ }^{2+} / \mathrm{a}_{\mathrm{Mg}^{2+}}\right)$ values calculated from the measured data using Equation 16 are $0.00 \pm 0.24$. This range encompasses all the $\log \left({ }^{\mathrm{a}^{2+}} / \mathrm{a}_{\mathrm{Mg}^{2+}}\right)$ values calculated from the water 
samples and shown in Figure 7. This also suggests that there are no systematic variations in the cation exchange properties of the formation that would lead to differences in the $\log \left(\mathrm{Ca}^{2+} / \mathrm{a}_{\mathrm{Mg}^{2+}}\right)$ values of the samples from the various boreholes.

There is a correlation between the $\log \left({ }^{\mathrm{a} \mathrm{a}^{2+}} / \mathrm{a}_{\mathrm{Mg}^{2+}}\right)$ values and the chloride contents of the water samples $\left(R^{2}=0.995\right)$. Several hypotheses can be advanced that would account for this.

First, it could be an artefact of the activity coefficient calculations. The BRGM database makes use of the ion-pairng model with individual ion activities calculated using the Helgeson B-dot form of the extended Debye-Hückel equation. The water analyses were also modelled with the Pitzer ion-interaction model by using database PITZER.DAT as supplied with the PHREEQC program (http://wwwbrr.cr.usgs.gov/projects/GWC_coupled/phreeqci/). The activities calculated by the two databases are virtually the same indicating that activity coefficients errors are unlikely to be a cause of the differences between the borehole values.

The second hypothesis is that the cation exchange model for divalent species may become less adequate as the solution chloride content increases. Underlying this hypothesis is the work of Charlet and Tournassat (2005) showing that there is preferential exchange of chloride-divalent ion pairs on clays in seawater and work of Ferrage et al. (2005) identifying $\mathrm{Ca}-\mathrm{Cl}$ ion pairs in montmorillionite interlayers. If chloride ion pairs are important exchangeable entities, they could well lead to cation exchange behaviour that varies with the solution chloride content but that would not be reflected in the models so far applied to the Opalinus Clay. Vinsot et al. (2008b) published pore water solution composition data obtained from in-situ borehole water sampling in Callovian-Oxfordian formation. Chloride concentrations range from 28 to $50 \mathrm{mmol} / \mathrm{L}$. Reported calcium and magnesium concentrations lead to a mean $\log \left(\mathrm{Ca}^{2+} / \mathrm{a}_{\mathrm{Mg}^{2+}}\right)$ of $0.05 \pm 0.04(2 \mathrm{SD}$ on 6 values) in near agreement with the 0.16 value expected at $25^{\circ} \mathrm{C}$. This value is also similar to the value obtained in Mont Terri BWSA-3 borehole, with the least saline borehole solution composition (120 $\mathrm{mmol} / \mathrm{L})$.

This examination of the controls on calcium and magnesium can be summarized as follows:

- The assumption that calcium and (or) carbonate concentrations are related to calcite equilibria is based on observations that ground waters in carbonate-bearing rocks are saturated with respect to this mineral. 
- Dolomite equilibrium, although it can be associated with the magnesium concentration of many ground waters, is not entirely consistent with the chemistry of pore water from all the Opalinus Clay boreholes sampled. The inconsistencies are relatively small and may be due to unreliable analytical data or thermodynamic properties. The minerals actually present in the Opalinus Clay may also not have the ideal composition of the database dolomite.

- The pore water calcium and magnesium contents are consistent with control by cation exchange but there is considerable variation in the measured in situ exchangeable cation populations. Including these variations in the modelling would lead to large uncertainties in calculated water compositions.

- There is apparent correlation between $\log \left(\mathrm{Ca}^{2+} / \mathrm{a}_{\mathrm{Mg}^{2+}}\right)$ values and chloride contents, for which there is as yet no explanation.

- To decide these questions about controls on calcium and magnesium concentrations and to improve the ability to model clay pore water will require further, more detailed consideration of:

- The reliability of the analytical data

- The precision of the cation exchange data

- The reliability of the thermodynamic data used

- The compositions of the minerals actually present in the formation and their effect on the thermodynamic properties of the minerals

- Whether any of these four types of data can be measured with sufficient precision to significantly improve the accuracy of pore water compositions modelled from rock properties.

\subsection{4 pH control: Incorporation of silicate minerals in modelling}

In the early models and in the models discussed by Pearson et al. (2003) the number of phases included was commonly insufficient to determine both the $\mathrm{pH}$ and the total carbonate content. As Table 2 shows, Beaucaire et al. (2000) specified total carbonate and associated $\mathrm{pH}$ with electroneutrality. Bradbury and Baeyens (1980) specified the $\mathrm{PCO}_{2}$ which, with carbonate established by calcite equilibria, determined the pH. In most of the model variations described by Pearson et al. (2003), the $\mathrm{PCO}_{2}$ was specified and $\mathrm{pH}$ was associated with solution electroneutrality. Exceptions were scenario A3-E. of the models of Pearson et al. 
(2003) (above, Section 2.1.2.2) and the modelling of Coudrain-Ribstein and Gouze (1993) (above, Section 2.1.2.1). In both cases, dolomite was associated with the total carbonate content because magnesium was associated with another reaction. In the former case, magnesium cation exchange was included; in the latter, equilibrium with Mg-chlorite was specified.

More recent modelling has explored equilibrium with the aluminosilicate minerals that make up much of the Opalinus Clay. As shown in Table A9.3 of Pearson et al. (2003) and in Wersin et al.(this issue a), these minerals are quartz $(6-32 \%)$, kaolinite $(15-35 \%)$, illite $(17-35 \%)$, mixed-layer illite/smectite $(5-20 \%)$, and chlorite (7-20\%). Quartz (or chalcedony) and kaolinite were included in a number of the early models, associated with dissolved silica and aluminium. The remainder of this section describes the inclusion of additional clay minerals in modelling Opalinus Clay pore water and in similar modelling of pore water from the COx at Bure

\subsubsection{THERMOAR modelling of Callovian-Oxfordian pore water}

Gaucher et al. $(2006,2009)$ developed an approach called THERMOAR modelling to calculate the chemistry of pore water in the COx at Bure based on formation properties measured on core samples. This modelling includes silicate minerals, the presence of which avoids the need to specify $\mathrm{pH}, \mathrm{PCO}_{2}$ or total carbonate. The formal relationships between phases and solution components in the reference and alternate models are shown in the fifth and sixth columns of Table 2 and in Table 4 of Gaucher et al. (2009). Because of the complex chemistry of most of the silicates, defining these relationships is not straightforward. The modelling was done using PHREEQC and the THERMODDEM (BRGM) database. The PHREEQC input files and the thermodynamic database used are given in the electronic annexes to Gaucher et al. (2009).

The nominal or reference model of Gaucher et al. (2009) is similar to previous models in that chloride and sulphate are specified in the input and the major cations are established by cation exchange and the electroneutrality constraint. Fe(II) in this model is also controlled by cation exchange. The modelling began by bringing a solution with chloride and sulphate contents determined by core leaching to equilibrium with an exchanger with populations and selectivity coefficients equal to those measured on core samples. The charge balance of the solution was maintained by adjusting sodium. This solution was initially oversaturated with celestite and gypsum indicating excess sulphate in the leaching results. This was corrected by bringing the solution to equilibrium with celestite. This lowered both the dissolved sulphate and strontium contents and the strontium content of the exchanger. Finally the solution was also brought to equilibrium with calcite, pyrite, quartz, Fe-chlorite (daphnite-14A in the database) $\left(\mathrm{Fe}_{5} \mathrm{Al}_{2} \mathrm{Si}_{3} \mathrm{O}_{10}(\mathrm{OH})_{8}\right)$ and illite (illite-Mg in the database) $\left(\mathrm{K}_{0.85} \mathrm{Mg}_{0.25} \mathrm{Al}_{2.35} \mathrm{Si}_{3.4} \mathrm{O}_{10}(\mathrm{OH})_{2}\right)$. Unlike the Opalinus Clay, the horizon of the COx examined by Gaucher et al. (2009) does not contain kaolinite. 
Calcite equilibrium established the carbonate content of the solution. Dissolution of this mineral also added small amounts of calcium to the solution and to the exchanger. Quartz dissolution established the dissolved silica content. Fe-chlorite dissolution established the dissolved aluminium concentration and added a corresponding small amount of Fe(II) to the solution and to the exchanger. Pyrite established the S(II) concentration which, with the sulphate (S(VI)) concentration, was used to calculate the redox potential of the solution. The final mineral, illite, specified the $\mathrm{pH}$ but its dissolution also influenced the dissolved and exchanged potassium and magnesium. A final check insured that the influence of mineral dissolution was negligible relative to the uncertainties in the measurements of exchangeable cation populations.

Several alternative models were also examined using other plausible minerals. These included the silicates designated in the database as chlorite-Cca2 $\left(\mathrm{Mg}_{2.97} \mathrm{Fe}_{1.92} \mathrm{Al}_{2.49} \mathrm{Ca}_{0.01} \mathrm{Si}_{2.63} \mathrm{O}_{10}(\mathrm{OH})_{8}\right)$ and Imt-2 illite $\left.\left(\mathrm{Na}_{0.044} \mathrm{~K}_{0.762}\right)\left(\mathrm{Si}_{3.387} \mathrm{Al}_{0.613}\right)\left(\mathrm{Al}_{1.427} \mathrm{Fe}_{0.376} \mathrm{Mg}_{0.241}\right) \mathrm{O}_{10}(\mathrm{OH})_{2}\right)$, and the carbonates siderite and dolomite. The structural formulae of chlorite-Cca2 and Imt-2-illite are more representative of the minerals present in the COx than the generic illite and daphnite used in the reference model and their solubilities have recently been determined calorimetrically (Gailhanou et al. 2007, 2009). As shown in Table 4 of Gaucher et al. (2009), the measured $\mathrm{pH}$ of COx water was $7.2 \pm 0.2$ and that of the reference model water was 7.1. $\mathrm{pH}$ values modelled with combinations of other silicate minerals tested were from 7.0 to 7.4. All models led to major ion concentrations closely similar to each other and to the measured values.

The thermodynamic properties of minerals like those used in these models are generally not precisely known for specific formations because of the variable compositions of such minerals. However, as Gaucher et al. (2009) point out, $\mathrm{pH}$ values are relatively insensitive to uncertainties in the solubility products of silicates included in the THERMOAR modelling. For example, for the reference model, $\mathrm{pH}$ can be expressed as:

$$
\mathrm{pH}=\frac{-0.85 \mathrm{pK}^{+}+5.875 \mathrm{pFe}^{2+}-0.25 \mathrm{pMg}^{2+}-\log \mathrm{K}_{\text {illite }}+1.175 \log \mathrm{K}_{\text {chlorite }}-0.125 \log \mathrm{K}_{\text {quartz }}}{10.4}
$$

in which, potassium, $\mathrm{Fe}(\mathrm{II})$ and $\mathrm{Mg}$ concentrations are associated with cation exchange. This equation indicates that an uncertainty of one $\log$ unit in the clay $\log \mathrm{K}$ values gives rise to an uncertainty of only 0.1 $\mathrm{pH}$ units.

\subsubsection{Modelling of Mont Terri PC-C borehole water including silicates}

The THERMOAR methodology has also been applied to water from the PC-C borehole at Mont Terri. The chloride concentration specified was the average of the borehole samples, but a value based on core leaching could also have been used. The sulphate content was based on the chloride content and the sulphate/chloride ratio of sea water, and was the same as the value measured in the borehole water (Figure 1). The major 
cations, sodium, potassium, magnesium, and calcium, were modelled with cation exchange using the populations shown in Table 3. These are based on values reported in Pearson et al. (2003) and values measured more recently on samples from the PC borehole. In the nominal case modelled and in all variations, saturation with calcite, celestite, siderite, quartz, and pyrite was specified. These minerals were associated with total carbonate, strontium, iron, silica and sulphide concentrations. As previously, the redox state was calculated from the sulphate/sulphide couple. Saturation with various pairs of the four clay minerals common to the Opalinus Clay was also specified. These minerals were associated with the aluminium concentration and the $\mathrm{pH}$. Finally, the effects on the modelled calcium and magnesium contents of specifying dolomite saturation was also examined. These associations are summarized in the last column of Table 2.

The specific minerals used for the modelling were Daphnite_14A, Chlorite CCa-2, Illite-Mg, Illite-Imt2, Kaolinite, and Mg-Montmorillonite-Na with compositions and properties given in the BRGM database.

The results of the calculations at $13^{\circ} \mathrm{C}$ with and without dolomite an celestite are shown in Tables 5 and 6 . The solute concentrations modelled without dolomite equilibrium agree well with the measured values except for iron and alkalinity. Iron concentrations in ground waters may be difficult to measure because sample oxidation can lead to lowered iron contents. An additional problem for modelling is that the solubility of the actual iron carbonate mineral in the formation may differ from the value for siderite in the database as, mentioned in Section 2.2.3, above. The choice of clay minerals used in the modelling has a noticeable effect only on the solution $\mathrm{pH}$, pe, and alkalinity. The modelled $\mathrm{pH}$ ranges from 7.3 to 7.8 which overlaps the average measured value of $7.1 \pm 0.4$. The modelled alkalinity values range from 0.5 to 1.5 meq $/ \mathrm{kg} \mathrm{H}_{2} \mathrm{O}$, and all are below the measured value of $3.82 \pm 0.68 \mathrm{meq} / \mathrm{kg} \mathrm{H}_{2} \mathrm{O}$. All the measured samples are oversaturated with calcite at $20^{\circ} \mathrm{C}$ (i.e the measurement temperature, Vinsot et al. $2008 \mathrm{Tab}$ 2). If modelled to calcite saturation, they would have had either lower $\mathrm{pH}$ or lower alkalinity values. The fact that the modelled alkalinity values vary by less than a factor of four in spite of the use of four different pairs of clay minerals supports the assumption that the pore water is in equilibrium with these clays and indicates that the thermodynamic data used for the modelling are not grossly inaccurate.

It would have been useful to compare modelled and measured $\mathrm{Al}$ concentrations but no $\mathrm{Al}$ data are available for the PC-C samples. Al concentrations are available for the BWSA-1 and -3 waters as shown in Table 1. There is considerable variability in these concentrations, possibly because they are so low they would be affected by the presence of even very small quantities of contaminating solids in the samples. In spite of this, the calculated Al values in Table 5 are consistent with those measured for BWSA-1 samples, the salinity of which is close to that of PC-C water. 
There is also good agreement between the modelled and measured exchangeable cation populations. The populations of all cations are virtually the same when modelled with various pairs of clay minerals. The modelled exchangeable calcium/magnesium ratio is slightly higher than that measured but is well within the uncertainty in the measured values. Likewise, the modelled calcium and magnesium contents of the water differ slightly from the measured values. This difference could be reduced by increasing the $\log K_{G-T}^{\mathrm{Na} / \mathrm{Ca}}$ and/or decreasing slightly the $\log K_{G-T}^{\mathrm{Na} / \mathrm{Mg}}$ values while remaining within range of values measured for the Opalinus clay fraction (see Table 4). Nearly perfect agreement between modelled and measured value is reached with $\log K_{G-T}^{N a / C a}=0.8$ and $\log K_{G-T}^{N a / M g}=0.6$ (in which case the calculated $\log \left(\mathrm{Ca}^{2+} / \mathrm{a}_{\mathrm{Mg}^{2+}}\right)$ is -0.1, i.e. the measured value).

Tables 5 and 6 also show the same set of models with dolomite saturation included. Agreement between the measured and modelled values is similar to that in the models without dolomite even for calcium and magnesium. This modelling result shows that predictive water composition calculations are not more accurate when considering only $\mathrm{Ca}-\mathrm{Mg}$ cation exchange rather than dolomite-calcite equilibrium if cation exchange selectivity coefficients are not very accurately known..

\subsubsection{Needs for improvement of recent models}

While recent modelling of Opalinus Clay pore waters has overcome some of the shortcomings of earlier models, several still remain and recent modelling itself is not without uncertainties. The principal need to improve future modelling is additional or better data on rock properties. In particular:

- No attempt to improve the description of pore water redox conditions was made in the recent modelling. To improve these models will require more detailed identification of phases in the Opalinus Clay that include redox-sensitive elements. In addition, the compositions and corresponding thermodynamic properties of these phases must be available.

- The relationship between sulphate and strontium concentrations and celestite saturation is not entirely clarified. An improved understanding of the distribution of celestite throughout the Opalinus Clay would provide insight to this question.

- At present, reactions affecting magnesium concentrations and calcium/magnesium ratios cannot be modelled precisely enough to be certain which is most important. Improvements in analytic and thermodynamic data and rock cation exchange and minerals chemical properties will be needed. It 
is uncertain whether the quality of such data can be improved sufficiently to decide the relative importance of possible reactions.

- The inclusion of clay mineral equilibria permits modelling of the $\mathrm{pH}$ without the need to specify $\mathrm{PCO}_{2}$ or total carbonate concentrations, or dolomite saturation. For this to be most successful, the identity, composition, and stability constants of minerals actually present in the formation should be available. Use of generic stability constants was successful in the case described here but this may have been fortuitous.

\section{SUMMARY AND CONCLUSIONS}

Pore waters in clay-rich rocks generally cannot be sampled directly. Instead, their chemistry must be found using the laboratory-measured properties of core samples and geochemical modelling. Many such measurements have been made on samples from the Opalinus Clay from the Mont Terri URL. Several boreholes in that URL yielded water samples against which pore water models have been calibrated.

Inputs to a pore water model must include a sufficient number of specified solute concentrations and equilibrium phases to satisfy Gibbs' Phase Rule. There are no mineral controls on chloride in Opalinus Clay pore water, so chloride concentrations must be specified in model input. These can be determined from aqueous leaching data and anion-accessible porosities of core samples. Sulphate is present in Opalinus Clay pore water at virtually the same ratio to chloride as it is in seawater. Celestite is present but uncommon in the Opalinus Clay and the more saline pore waters appear to be saturated with respect to it. Sulphate concentrations are generally specified in the modelling but celestite saturation is included in some model variations.

The first Opalinus Clay modelling was done before pore water samples were available (Bradbury et al. 1997-1998; Bradbury and Baeyens 1998). This modelling included saturation with calcite and dolomite, and cation exchange equilibria among sodium, potassium, and calcium. The exchangeable cation populations and selectivity coefficients used for the cation exchange modelling were measured on Opalinus Clay samples. Chloride was specified and the solution electroneutrality constraint was included in the modelling. The $\mathrm{PCO}_{2}$ of the water was also specified.

Similar modelling of ground waters and pore waters from other formations has been done specifying sodium and potassium concentrations with feldspars, kaolinite and chalcedony saturation instead of with cation exchange. These models also included calcite and dolomite saturation. One of them (Coudrain-Ribstein and Gouze 1993) included Mg-chlorite and anhydrite saturation. With these, the system was fully constrained and the $\mathrm{pH}$, total carbonate, and $\mathrm{PCO}_{2}$ of the water could be calculated. Another model (Beaucaire et al. 2000) specified total carbonate in the input and did not include sulphate. Feldspar equilibria are not included 
in Opalinus Clay modelling because feldspars are present only in very small quantities in the formation and because sodium/potassium ratios measured in pore water samples are inconsistent with feldspar saturation.

Modelling supported by numerous measurements of core properties and many analyses of pore water samples was described by Pearson et al. (2003). This modelling was based on specified chloride, sulphate, and $\mathrm{PCO}_{2}$ values, calcite, dolomite, kaolinite and quartz saturation, and sodium, potassium, calcium, and strontium cation exchange. In some model variations, magnesium exchange replaced dolomite saturation and celestite saturation replaced strontium exchange. Redox was included based on the S(VI)/S(-II) couple with S(-II) established by pyrite and siderite saturation. Scenarios with goethite and microcrystalline $\mathrm{Fe}(\mathrm{OH})_{3}$ replacing siderite and with the $\mathrm{Fe}(\mathrm{III}) / \mathrm{Fe}(\mathrm{II})$ couple replacing $\mathrm{S}(\mathrm{VI}) / \mathrm{S}(-\mathrm{II})$ were also tested. Redox conditions established with the S(VI)/S(-II) couple and siderite equilibrium were most consistent with measured concentrations of the redox-sensitive elements iron, manganese, and uranium. The principal shortcomings of the 2003 modelling were: an inability to model the potassium concentrations correctly with the measured cation exchange properties; a lack of consistency between measured magnesium and calcium concentrations and those modelled with magnesium exchange, and calcite and dolomite saturation; and an inability to reproduce the measured carbonate chemistry and $\mathrm{pH}$ of the pore waters using mineral-water reactions alone.

These shortcomings have been largely overcome in recent modelling. It has been found (Tournassat et al. 2007, 2009) that selectivity coefficients for sodium/potassium exchange used in the earlier modelling were too weak. Using stronger coefficients appropriate to the low exchangeable potassium population of the Opalinus Clay reproduces the measured pore water potassium concentrations.

Re-examination of the measured calcium/magnesium activity ratios and consideration of the mineralogical composition of the Opalinus Clay suggested that calcium/magnesium cation exchange rather than dolomite saturation may control the ratio of these ions in solution. This re-examination also suggests that the calcium/magnesium ratio decreases with increasing pore water salinity. Several possible reasons for this are proposed but not explored further in this paper.

Following the example of recent modelling of pore water from the Callovo-Oxfordian at Bure (Gaucher et al. 2006, 2009), saturation with clay minerals has been included in recent Opalinus Clay modelling. These additional minerals eliminate the need to specify $\mathrm{pH}$ or total carbonate in the model input. The clay minerals present in the Opalinus Clay are kaolinite, chlorite, and illite/smectite. Water from the PC-C borehole was modelled with six scenarios, each with one of the possible pairs of these minerals. When dolomite saturation is not included, modelled solute concentrations and exchangeable cation contents agree with the measured values, and the modelled $\mathrm{pH}$ ranges from 7.3 to 7.8 at $13^{\circ} \mathrm{C}$, comparing well with the measured value of $7.1 \pm 0.4$. 


\section{ACKNOWLEDGEMENTS}

This work was undertaken in close co-operation with, and with the financial support of the Mont-Terri Consortium, ANDRA and Nagra. We appreciate fruitful discussions with Agnes Vinsot, Paul Wersin, Olivier Leupin, Suzanne Mettler, Tres Thoenen and Scott Altmann, during the Porewater Chemistry and the Geochemical Data Experiments. Many thanks also to the Mont Terri team, including Christophe Nussbaum and Paul Bossart (Swisstopo), for their continuous support to the project. We also appreciate the comments of two anonymous referees for the jopurnal.

\section{REFERENCES}

Appelo, C. A. J., Ponten, J., and Beekman, H. E., 1989, Natural ion-chromatography during fresh-/sea water displacements in aquifers: A hydrogeochemical model of the past, in Miles, Douglas L., ed., WaterRock Interaction WRI-6: Proceedings of the 6th International Symposium on Water Rock Interaction, Malvern, Rotterdam, A.A. Balkema, p. 23-28.

Appelo, C. A. J., Vinsot, A., Mettler, S, and Wechner, S., 2008, Obtaining the porewater composition of a clay rock by modeling the in- and out-diffusion of anions and cations from an in-situ experiment.: Journal of Contaminant Hydrology, v. 101, p. 67-76.

Baeyens, Bart, and Bradbury, Michael H., 1994, Phyisco-Chemical Characterisation and Calculated In Situ Porewater Chemistries for a Low Permeability Palfris Marl Sample from Wellenberg: Wettingen, Switzerland, Nagra Technical Report 94-22, 30 p.

Baeyens, B. and Bradbury, M., 2004. Cation exchange capacity measurements on illite using the sodium and cesium isotope dilution technique: effects of the index cation, electrolyte concentration and competition: modeling. Clays and. Clay. Minerals, v. 52, p. 421-431.

Baeyens, B., Maes, A., Cremers, A., and Henrion, P. N., 1985a, In Situ Physico-Chemical Characterization of Boom Clay: Radioactive Waste Management and the Nuclear Fuel Cycle, v. 6, p. 391-408.

Baeyens, B., Maes, A., Cremers, A., and Henrion, P. N., 1985b, Aging Effects in Boom Clay: Radioactive Waste Management and the Nuclear Fuel Cycle, v. 6, p. 409-423.

Beaucaire, C., Pitsch, H., Toulhoat, P., Motellier, S., and Louvat, D., 2000, Regional fluid characterisation and modelling of water-rock equilibria in the Boom clay Formation and in the Rupelian aquifer at Mol, Belgium: Applied Geochemistry, v. 15, no. 5, p. 667-686. 
Blanc P., Lassin A., and Piantone P., 2007, THERMODDEM A Database Devoted to Waste Materials, BRGM, Orleans, France, http://thermoddem.brgm.fr.

Bowers, T. S., Jackson, K. J., and Helgeson, H. C., 1984, Equilibrium Activity Diagrams for Coexisting Mineral and Aqueous Solutions at Pressures and Temperatures to $5 \mathrm{~kb}$ and $600^{\circ} \mathrm{C}$ : Berlin, SpringerVerlag, $367 \mathrm{p}$.

Bradbury, M. H., and Baeyens, B., 1998, A physiochemical characterisation and geochemical modelling approach for determining porewater chemistries in argillaceous rocks: Geochimica et Cosmochimica Acta, v. 62 , no. 5, p. 783-795.

Bradbury, M. H. and Baeyens, B., 2000. A generalised sorption model for the concentration dependent uptake of caesium by argillaceous rocks. Journal of Contaminant. Hydrolology.v. 42, p. 141-163.

Bradbury, M. H., Baeyens, B., Pearson, F. J., and Berner, U., 1997-1998, Derivation of In Situ Opalinus Clay Porewater Compositions from Experimental and Geochemical Modelling Studies with Addendum: Wettingen, Switzerland, Nagra, Technical Report 97-07, 50 + 13 p.

Charlet, Laurent, and Tournassat, Christophe, 2005, $\mathrm{Fe}(\mathrm{II})-\mathrm{Na}(\mathrm{I})-\mathrm{Ca}(\mathrm{II})$ cation exchange on montmorillonite in chloride medium: Evidence for preferential clay adsorption of chloride-metal ion pairs in seawater: Aquatic Geochemistry, v. 11, p. 115-137.

Coudrain-Ribstein, A., and Gouze, P., 1993, Quantitative study of geochemical processes in the Dogger aquifer, Paris Basin, France: Applied Geochemistry, v. 8, p. 495-506.

Deer, W. A., Howie, R. A., and Zussman, J., 1992, An Introduction to the Rock-Forming Minerals, Second Edition: Harlow, England, Longman Scientific \& Technical, 696 p.

Degueldre, Claude, Scholtis, Andreas, Laube, Andreas, Turrero, María Jesús, and Thomas, Bertrand, 2003, Study of the pore water chemistry through an argillaceous formation: a paleohydrochemical approach: Applied Geochemistry, v. 18, p. 53-73.

Ferrage, Eric, Tournassat, Christophe, Rinnert, Emmanuel, Charlet, Laurent, and Lanson, Bruno, 2005, Experimental evidence for Ca-chloride ion pairs in the interlayer of montmorillonite. An XRD profile modeling approach: Clays and Clay Minerals, v. 53, p. 348-360. 
Foster, Margaret D., 1950, The origin of high sodium bicarbonate waters in the Atlantic and Gulf Coastal Plains: Geochimica et Cosmochimica Acta, v. 1, p. 33-48.

Gailhanou, H., van Miltenberg, J. C., Rogez, J., Olives, J., Amouric, M., Gaucher, E. H., and Blanc, P., 2007, Thermodynamic properties of anhydrous smectite MX-80, illite IMt-2 and mixed-layer illitesmectite ISCz-1 as determined by calorimetric methods. Part I: Heat capacities, heat contents and entropies.: Geochimica et Cosmochimica Acta, v. 71, p. 5463-5473.

Gailhanou, H., Rogez, J., van Miltenberg, J. C., van Genderen, A. C. G., Greneche, J. M., Gilles, C., Jalabert, D., Michau, N., Gaucher, E. H., and Blanc, P., 2009, Thermodynamic properties of chlorite CCa-2. Heat capacities, heat contents and entropies.: Geochimica et Cosmochimica Acta, v. 73, p. 4738-4749.

Gaines, George L. Jr., and Thomas, Henry C., 1953, Adsorption studies on clay minerals. II. A formulation of the thermodynamics of exchange adsorption: The Journal of Chemical Physics, v. 21, p. 714-718.

Garrels, R. M., and Christ C. L., 1965, Solutions, minerals, and equilibria: New York, Harper \& Row, 450 p.

Garrels, R. M., and Thompson, M. E., 1962, A Chemical Model for Sea Water at $25^{\circ} \mathrm{C}$ and One Atmosphere Total Pressure: American Journal of Science, v. 260, p. 57-66.

Gaucher, Éric C, Blanc, Philippe, Bardot, Frédérique, Braibant, Gilles, Buschaert, Stéphane, Crouzet, Catherine, Gautier, Anne, Girard, Jean-Pierre, Jacquot, Emmanuel, Lassin. Arnault, Negrel, Gabrielle, Tournassat, Christophe, Vinsot, Agnès, and Altmann, Scott, 2006, Modelling the porewater chemistry of the Callovian-Oxfordian formation at a regional scale: Comptes Rendu Geosciences, v. 338, p. 917-930.

Gaucher, E. C., Tournassat, C., Pearson, F. J., Blanc, P., Crouzet, C., Lerouge, C., and Altmann, S., 2009, A robust model for pore-water chemistry of clayrock: Geochimica et Cosmochimica Acta, v. 73, p. 6470-6487.

Hemingway, B.S., Robie, R.A., 1994. Enthalpy and Gibbs energy of formation of dolomite, $\mathrm{CaMg}(\mathrm{CO} 3) 2$, at 298.15 K from $\mathrm{HCl}$ solution calorimetry. U.S. Geological Survey Open-file Rep. 94-575. 
Hummel, Wolfgang, Berner, Urs, Curti, Enzo, Pearson, F. J., and Thoenen, Tres, 2002, Nagra / PSI

Chemical Thermodynamic Data Base 01/01: Parkland, Florida, Universal Publishers/uPublish.com, 565 p. (Also published as Wettingen, Switzereland, Nagra Technical Report NTB 02-16).

Hutcheon, Ian, and Abercrombie, Hugh, 1990, Carbon dioxide in clastic rocks and silicate hydrolysis: Geology, v. 18, p. 541-544.

Jensen, Mark, Lam, Tom, Luhowy, Dylan, McLay, Jim, Semec, Branko, and Frizzell. Robin, 2010, Ontario Power Generation's proposed L \& ILW Deep Geologic Repository: An Overview of Geoscientific Studies, GeoHalifax'2009: 62nd Canadian Geotechnical Conference and 10th Joint CGS/ IAHCNC Groundwater Specialty Conference, 20-24 September 2009, Halifax, Nova Scotia, p. 13391347.

Johnson, James W., Oelkers, Eric H., and Helgeson, Harold C., 1992, SUPCRT92 - A software package for calculating the standard molal thermodynamic properties of minerals, gases, aqueous species, and reactions from 1-bar to 5000-bar and 0 to 1000-degrees-C: Computers \& Geosciences, v. 18, p. 899947.

Koroleva, M., Lerouge, C., Mäder, U., Claret, F., and Gaucher, E. C., This issue, Overcoring of a microbially perturbed in-situ pore water chemistry experiment in Opalinus Clay at Mont Terri: Evidence of strong buffering by the rock formation.

Korzhinskii, D. S., 1965, The theory of systems with perfectly mobile components and processes of mineral formation: American Journal of Science, v. 263, p. 193-205.

Langmuir, Donald, 1997, Aqueous Environmental Chemistry: Upper Saddle River, New Jersey, Prentice Hall, $600 \mathrm{p}$.

Mazurek, Martin, Alt-Epping, Peter, Bath, Adrian, Gimmi, Thomas, and Waber, H. Niklaus, 2009, Natural Tracer Profiles Across Argillaceous Formations: The CLAYTRAC Project: Paris, Nuclear Energy Agency, OECD NEA No. 6253, 361 p.

Michard, G, 1983, Recueil des donées thermodynamiques concernant les équilibres eaux-minéaux dans les réservoirs hydrothermaux, CCE EUR 8590 FR. 
Nagra, 1997, Geosynthese Wellenberg 1996, Ergebnisse der Untersuchungsphasen I und II.: Wettingen, Switzerland, Nagra, Technischer Bericht 96-01, 2 volumes .

Parkhurst, David L., and Appelo, C. A. J., 1999, User's Guide to PHREEQC (Version 2) - A Computer Program for Speciation, Batch-Reaction, One-Dimensional Transport, and Inverse Geochemical Calculations: Denver, CO, U. S. Geological Survey, Water-Resources Investigations Report 99$4259,312 \mathrm{p}$.

Pearson, F. J., 1999, What is the porosity of a mudrock?, in Aplin, A. C., Fleet, A. J., and Macquaker, J. H. S., eds., Muds and Mudstones: Physical and Fluid Flow Properties: London, Geological Society, Special Publications, 158, p. 9-21.

Pearson, F. J. Jr., and White, D. E., 1967, Carbon 14 Ages and Flow Rates of Water in Carrizo Sand, Atascosa County, Texas: Water Resources Research, v. 3, p. 251-261.

Pearson, F. J. Jr., Fisher, D. W., and Plummer, L. N., 1978, Correction of ground-water chemistry and carbon isotopic composition for effects of $\mathrm{CO} 2$ outgassing: Geochimica et Cosmochimica Acta, $\mathrm{v}$. 42, p. 1799-1807.

Pearson, F. J. Jr., Lolcama, J. L., and Scholtis, A., 1989, Chemistry of Waters in the Böttstein, Weiach, Riniken, Schafisheim, Kaisten and Leuggern Boreholes: A Hydrochemically Consistent Data Set: Baden, Switzerland, Nagra, Technical Report 86-19, 43 p.

Pearson, F. J., Arcos, D., Bath, A., Boisson, J.-Y., Fernández, A. Mª., Gäbler, H.-E., Gaucher, E., Gautschi, A., Griffault, L., Hernán, P., and Waber, H. N., 2003, Mont Terri Project - Geochemistry of Water in the Opalinus Clay Formation at the Mont Terri Rock Laboratory: Bern, Switzerland, Federal Office for Water and Geology (FOWG), Geology Series 5, 319 p.

Poinssot, C., Baeyens, B., and Bradbury, M. H., 1999. Experimental and modelling studies of caesium sorption on illite. Geochimica et Cosmochimica Acta, v. 63, p. 3217-3227.

Steefel, C. I., Carroll, S., Zhao, P., and Roberts, S., 2003. Cesium migration in Hanford sediment: a multisite cation exchange model based on laboratory transport experiments. Journal of Contaminant Hydrology v. 67, p. 219-246. 
Stefánsson, Andri, and Arnórsson, Stefán, 2000, Feldspar saturation state in natural waters: Geochimica et Cosmochimica Acta, v. 64, p. 2567-2584.

Thompson, J. B. Jr., 1955, The thermodynamic basis for the mineral facies concept: American Journal of Science, v. 253, p. 65-103.

Thorstenson, Donald C., Fisher, Donald W., and Croft, Mack G., 1979, The geochemistry of the Fox HillsBasal Hell Creek aquifer in southwestern North Dakota and northwestern South Dakota: Water Resources Research, v. 15, no. 6, p. 1479-1498.

Tournassat, Christophe, Gailhanou, Hélène, Crouzet, Catherine, Braibant, Gilles, Gautier, Anne, Lassin, Arnault, Blanc, Philippe, and Gaucher, Eric C., 2007, Two cation exchange models for direct and inverse modelling of solution major cation composition in equilibrium with illite surfaces: Geochimica et Cosmochimica Acta, v. 71, p. 1098-1114.

Tournassat, Christophe, Lerouge, Catherine, Blanc, Philippe, Brendlé, Jocelyne, Greneche, Jean-Marc, Touzelet, Stéphane, and Gaucher, Eric C., 2008, Cation exchanged Fe(II) and Sr compared to other divalent cations $(\mathrm{Ca}, \mathrm{Mg})$ in the bure Callovian-Oxfordian formation: Implications for porewater composition modelling: Applied Geochemistry, v. 23, p. 641-654.

Tournassat, Christophe, Gailhanou, Hélène, Crouzet, Catherine, Braibant, Gilles, Gautier, Anne, and Gaucher, Eric C., 2009, Cation exchange selectivity coefficient values on smectite and mixed-layer illite/smectite minerals: Soil Science Society of America Journal, v. 73, no. 3, p. 928-942.

Tournassat, Christophe, Alt-Epping, Peter, Gaucher, Eric C., Gimmi, Thomas, Leupin, Olivier, and Wersin, Paul, This issue, Part F Porewater Chemistry Experiment at Mont Terri Rock Laboratory. Reactive Transport Modelling: Applied Geochemistry.

Van Loon, L. R., Soler, J. M., and Bradbury, M. H., 2003, Diffusion of $\mathrm{HTO}^{36} \mathrm{Cl}^{-}$and ${ }^{125} \mathrm{I}^{-}$in Opalinus Clay samples form Mont Terri: Effect of confining pressure.: Jounrnal of Contaminant Hydrology, v. 61, p. 73-83.

Van Loon, Luc R., and Soler, Josep M., 2004, Diffusion of HTO, ${ }^{36} \mathrm{Cl}^{-},{ }^{125} \mathrm{I}^{-}$and ${ }^{22} \mathrm{Na}^{+}$in Opalinus Clay: Effect of Confining Pressure, Sample Orientation, Sample Depth and Temperature: Villigen PSI, Switzerland, Paul Scherrer Institut, PSI Bericht 04-03, 120 p. (Also published as Wettingen, Switzerland, Nagra Technical Report NTB 03-07). 
Vinsot, A., Appelo, C. A. J., Cailteau, C., Wechner, S., Pironon, J., De Donato, P., De Canničre, P., Mettler, S., Wersin, P., and Gäbler, H.-E., 2008a, $\mathrm{CO}_{2}$ data on gas and pore water sampled in situ in the Opalinus Clay at the Mont Terri rock laboratory, in: Proceedings of the International Meeting on Clay in Natural and Engineered Barriers for Radioactive Waste Confinement, Lille, 2007, Physics and Chemistry of the Earth 33, p. S54-S60.

Vinsot, A., Mettler, S., and Wechner, S., 2008b. In situ characterization of the Callovo-Oxfordian pore water composition. Physics and Chemistry of the. Earth. v. 33, p. S75-S86.

Way, Thomas J., 1852, On the power of soils to absorb manure: Journal of the Royal Agricultural Society of England, v. 13, p. 123-143.

Wersin, P., Gaucher, E., Gimmi, Th., Leupin, O., Mäder, U., Pearson, F. J., Thoenen, T., and Tournassat, Ch., 2009, Geochemistry of pore waters in Opalinus Clay at Mont Terri: experimental data and modelling: St-Ursanne, Switzerland, Mont Terri Project, Technical Report 2008-06, 155 pp.

Wersin, P., Leupin, O., Mettler, S., Gaucher, E., Mäder, U., Vinsot, A., De Cannière, P., Gäbler, H. E., Kunimaro, T., and Kiho, K., This issue a, Part A: Overview, Experimental Design and Water Data: Applied Geochemistry. 
Table 1: Composition of water samples from boreholes PC-C, BWS-1 and BWSA-3 in Mont Terri URL.

Averages and 1 standard deviation values are of analyses given by Vinsot et al. (2008),

Pearson et al.(2003) and Wersin et al. (2009).

\begin{tabular}{|ll|ccc|ccc|ccc|}
\hline & & \multicolumn{3}{|c|}{ PC-C } & \multicolumn{2}{c|}{ BWSA-1 } & \multicolumn{3}{c|}{ BWSA-3 } \\
& & Mean & & Std Dev & Mean & & Std Dev & Mean & & Std Dev \\
$\mathrm{pH}$ value & & 7.13 & \pm & 0.23 & 7.55 & \pm & 0.38 & 7.41 & \pm & 0.15 \\
$\mathrm{Na}$ & $(\mathrm{mol} / \mathrm{L})$ & $2.81 \mathrm{E}-01$ & \pm & $5.55 \mathrm{E}-03$ & $2.32 \mathrm{E}-01$ & \pm & $1.22 \mathrm{E}-02$ & $1.22 \mathrm{E}-01$ & \pm & $6.12 \mathrm{E}-03$ \\
$\mathrm{~K}$ & $(\mathrm{~mol} / \mathrm{L})$ & $1.92 \mathrm{E}-03$ & \pm & $7.24 \mathrm{E}-04$ & $1.47 \mathrm{E}-03$ & \pm & $1.94 \mathrm{E}-04$ & $9.07 \mathrm{E}-04$ & \pm & $2.07 \mathrm{E}-04$ \\
$\mathrm{Mg}$ & $(\mathrm{mol} / \mathrm{L})$ & $2.20 \mathrm{E}-02$ & \pm & $4.80 \mathrm{E}-04$ & $1.66 \mathrm{E}-02$ & \pm & $6.80 \mathrm{E}-04$ & $5.93 \mathrm{E}-03$ & \pm & $2.23 \mathrm{E}-04$ \\
$\mathrm{Ca}$ & $(\mathrm{mol} / \mathrm{L})$ & $1.89 \mathrm{E}-02$ & \pm & $5.48 \mathrm{E}-04$ & $1.58 \mathrm{E}-02$ & \pm & $7.23 \mathrm{E}-04$ & $6.83 \mathrm{E}-03$ & \pm & $3.85 \mathrm{E}-04$ \\
$\mathrm{Sr}$ & $(\mathrm{mol} / \mathrm{L})$ & $4.59 \mathrm{E}-04$ & \pm & $6.24 \mathrm{E}-05$ & $4.63 \mathrm{E}-04$ & \pm & $2.34 \mathrm{E}-05$ & $3.51 \mathrm{E}-04$ & \pm & $2.30 \mathrm{E}-05$ \\
$\mathrm{Cl}$ & $(\mathrm{mol} / \mathrm{L})$ & $3.27 \mathrm{E}-01$ & \pm & $5.63 \mathrm{E}-03$ & $2.76 \mathrm{E}-01$ & \pm & $1.76 \mathrm{E}-02$ & $1.24 \mathrm{E}-01$ & \pm & $9.18 \mathrm{E}-03$ \\
$\mathrm{Br}$ & $(\mathrm{mol} / \mathrm{L})$ & $5.54 \mathrm{E}-04$ & \pm & $4.40 \mathrm{E}-04$ & $4.63 \mathrm{E}-04$ & \pm & $0.00 \mathrm{E}+00$ & $1.94 \mathrm{E}-04$ & \pm & $9.17 \mathrm{E}-06$ \\
$\mathrm{SO} 4$ & $(\mathrm{~mol} / \mathrm{L})$ & $1.68 \mathrm{E}-02$ & \pm & $8.77 \mathrm{E}-04$ & $1.26 \mathrm{E}-02$ & \pm & $1.96 \mathrm{E}-03$ & $7.79 \mathrm{E}-03$ & \pm & $1.95 \mathrm{E}-03$ \\
$\mathrm{Alkalinity}$ & $(\mathrm{eq} / \mathrm{L})$ & $4.00 \mathrm{E}-03$ & \pm & $8.04 \mathrm{E}-04$ & $1.22 \mathrm{E}-03$ & \pm & $6.22 \mathrm{E}-04$ & $3.35 \mathrm{E}-03$ & \pm & $1.41 \mathrm{E}-03$ \\
$\mathrm{Total} \mathrm{CO2}$ & $(\mathrm{mol} / \mathrm{L})$ & $3.89 \mathrm{E}-03$ & \pm & $5.60 \mathrm{E}-04$ & $1.24 \mathrm{E}-03$ & \pm & $6.61 \mathrm{E}-04$ & $4.47 \mathrm{E}-03$ & \pm & $4.15 \mathrm{E}-03$ \\
$\mathrm{Fe}$ & $(\mathrm{mol} / \mathrm{L})$ & $2.96 \mathrm{E}-05$ & \pm & $1.19 \mathrm{E}-05$ & $3.68 \mathrm{E}-06$ & \pm & $6.03 \mathrm{E}-06$ & $1.67 \mathrm{E}-06$ & \pm & $6.36 \mathrm{E}-10$ \\
$\mathrm{Al}$ & $(\mathrm{mol} / \mathrm{L})$ & & \pm & & $2.21 \mathrm{E}-06$ & \pm & $2.74 \mathrm{E}-06$ & $2.11 \mathrm{E}-07$ & \pm & $2.26 \mathrm{E}-08$ \\
$\mathrm{Si}$ & $(\mathrm{mol} / \mathrm{L})$ & $1.65 \mathrm{E}-04$ & \pm & $4.91 \mathrm{E}-05$ & $5.74 \mathrm{E}-05$ & \pm & $2.46 \mathrm{E}-05$ & $1.69 \mathrm{E}-04$ & \pm & $1.48 \mathrm{E}-04$ \\
\hline
\end{tabular}


Table 2: Correspondence between solution composition variables and constraints on their concentrations in various pore water equilibrium models.

\begin{tabular}{|c|c|c|c|c|c|c|c|}
\hline & $\begin{array}{c}\text { Coudrain-Ribstein and } \\
\text { Gouze (1993) } \\
\text { Tab } 1 \text { \& Fig } 5\end{array}$ & Beaucaire et al. (2000) & $\begin{array}{c}\text { Bradbury \& Baeyens } \\
\text { (1998) }\end{array}$ & $\begin{array}{l}\text { Pearson et al. (2003) } \\
\text { Table 5.8 }\end{array}$ & $\begin{array}{l}\text { COX Reference model } \\
\text { (Gaucher } \text { et al (2006, } \\
\text { 2009) }^{(1),(2)}\end{array}$ & $\begin{array}{l}\text { COX Alternate models } \\
\text { (Gaucher et al (2006, } \\
\text { 2009) }^{(1),(3)}\end{array}$ & $\begin{array}{l}\text { PC-C pore-water } \\
\text { calculation }\end{array}$ \\
\hline & $\begin{array}{l}\text { Dogger Aquifer, } \\
\text { Paris Basin }\end{array}$ & $\begin{array}{c}\text { Rupelian Aquifer } \\
\text { and Boom Clay, } \\
\text { Belgium }\end{array}$ & $\begin{array}{l}\text { Opalinus Clay at } \\
\text { Mont Terri, } \\
\text { Switzerland }\end{array}$ & $\begin{array}{l}\text { Opalinus Clay at } \\
\text { Mont Terri, } \\
\text { Switzerland }\end{array}$ & $\begin{array}{l}\text { Callovo-Oxfordian } \\
\text { (COx) at Bure, } \\
\text { France }\end{array}$ & $\begin{array}{l}\text { Callovo-Oxfordian } \\
\text { (COx) at Bure, } \\
\text { France }\end{array}$ & $\begin{array}{l}\text { Opalinus Clay at } \\
\text { Mont Terri, } \\
\text { Switzerland }\end{array}$ \\
\hline \multirow[t]{2}{*}{$\begin{array}{c}\text { Source of } \\
\text { thermodynamic } \\
\text { data used }\end{array}$} & Michard (1983) & $\begin{array}{c}\text { Principally Michard } \\
\text { (1983) }\end{array}$ & $\begin{array}{l}\text { Pearson and Berner } \\
\text { (1991); Pearson et al. } \\
\text { (1992) }\end{array}$ & $\begin{array}{c}\text { Nagra/PSI } \\
\text { Hummel et al. (2002) }\end{array}$ & $\begin{array}{c}\text { THERMODDEM } \\
\text { http://thermoddem.brg } \\
\frac{\text { m.fr/index.asp?langue }}{\text { =GB }}\end{array}$ & $\begin{array}{c}\text { THERMODDEM } \\
\text { http://thermoddem.brg } \\
\frac{\text { m.fr/index.asp?langue }}{\underline{=G B}}\end{array}$ & $\begin{array}{c}\text { THERMODDEM } \\
\text { http://thermoddem.brg } \\
\frac{\text { m.fr/index.asp?langue }}{\text { =GB }}\end{array}$ \\
\hline & \multicolumn{7}{|c|}{ Constraint on Element Concentration } \\
\hline $\begin{array}{c}\mathrm{Cl}^{-} \\
\text {Mobile element }\end{array}$ & $\begin{array}{l}\text { Fixed at average } \\
\text { value of water } \\
\text { samples }\end{array}$ & Fixed & $\begin{array}{l}\text { Calculated using bulk } \\
\text { rock content from } \\
\text { leaching and several } \\
\text { estimated values of } \\
\text { anion accessible } \\
\text { porosity }\end{array}$ & $\begin{array}{l}\text { Fixed at average values } \\
\text { measured in borehole } \\
\text { samples }\end{array}$ & $\begin{array}{l}\text { Calculated using bulk } \\
\text { rock content from } \\
\text { leaching and } \\
\text { geochemical porosity } \\
\text { evaluated from } \\
\text { comparison of leachable } \\
\mathrm{Cl} \text { in clay-rich and } \\
\text { carbonate-rich horizons }\end{array}$ & $\begin{array}{l}\text { Calculated using bulk } \\
\text { rock content from } \\
\text { leaching and } \\
\text { geochemical porosity } \\
\text { evaluated from } \\
\text { comparison of leachable } \\
\mathrm{Cl} \text { in clay-rich and } \\
\text { carbonate-rich horizons }\end{array}$ & $\begin{array}{l}\text { Fixed at average values } \\
\text { measured in borehole } \\
\text { samples }\end{array}$ \\
\hline $\begin{array}{l}\quad \mathrm{SO}_{4}{ }^{2-} \\
\text { Mobile or } \\
\text { controlled } \\
\text { element }\end{array}$ & Anhydrite saturation & & $\begin{array}{l}\text { Calculated using bulk } \\
\text { rock content from } \\
\text { leaching and several } \\
\text { estimated values of } \\
\text { anion accessible } \\
\text { porosity Decreased as } \\
\text { necessary to avoid } \\
\text { gypsum over-saturation }\end{array}$ & $\begin{array}{l}\text { Fixed at } \mathrm{SO}_{4} / \mathrm{Cl} \text { ratio in } \\
\text { seawater } \\
\qquad \mathrm{OR} \\
\text { Calculated from } \\
\text { celestite saturation } \\
\text { and } \mathrm{Na}-\mathrm{Sr} \text { exchange } \\
\text { (A3-C) }\end{array}$ & $\begin{array}{l}\text { Calculated from } \\
\text { leaching data, adjusted } \\
\text { for consistency with } \\
\text { celestite saturation and } \\
\text { Na-Sr exchange }\end{array}$ & $\begin{array}{l}\text { Calculated from } \\
\text { leaching data, adjusted } \\
\text { for consistency with } \\
\text { celestite saturation and } \\
\text { Na-Sr exchange }\end{array}$ & $\begin{array}{l}\text { Fixed at } \mathrm{SO}_{4} / \mathrm{Cl} \text { ratio in } \\
\text { seawater }\end{array}$ \\
\hline
\end{tabular}




\begin{tabular}{|c|c|c|c|c|c|c|c|}
\hline & $\begin{array}{c}\text { Coudrain-Ribstein and } \\
\text { Gouze (1993) } \\
\text { Tab } 1 \& \text { Fig } 5\end{array}$ & Beaucaire et al. (2000) & $\begin{array}{c}\text { Bradbury \& Baeyens } \\
\text { (1998) }\end{array}$ & $\begin{array}{l}\text { Pearson et al. }(2003) \\
\quad \text { Table } 5.8^{(4)}\end{array}$ & $\begin{array}{l}\text { COX Reference model } \\
\text { (Gaucher } \text { et al (2006, } \\
\text { 2009) }^{(1),(2)}\end{array}$ & $\begin{array}{l}\text { COX Alternate models } \\
\text { (Gaucher et al (2006, } \\
\text { 2009) }^{(1),(3)}\end{array}$ & $\begin{array}{l}\text { PC-C pore-water } \\
\text { calculation }\end{array}$ \\
\hline $\begin{array}{l}\quad \text { Carbonate } \\
\text { Mobile or } \\
\text { controlled } \\
\text { element }\end{array}$ & Dolomite saturation & $\begin{array}{l}\text { Fixed at regional total } \\
\text { carbonate }\end{array}$ & $\begin{array}{l}\mathrm{CO}_{3}{ }^{2-} \text { from calcite } \\
\text { saturation }\end{array}$ & $\begin{array}{l}\mathrm{pCO}_{2} \text { fixed at values } \\
\text { calculated from } \\
\text { borehole sample data. } \\
\qquad \mathrm{OR} \\
\mathrm{CO}_{3}^{2-} \text { from dolomite } \\
\text { saturation with } \mathrm{Mg} \\
\text { fixed by } \mathrm{Na}-\mathrm{Mg} \\
\text { exchange (A3-E) }\end{array}$ & Calcite saturation & Calcite saturation & $\begin{array}{l}\mathrm{CO}_{3}{ }^{2-} \text { from calcite } \\
\text { saturation }\end{array}$ \\
\hline $\begin{array}{l}\text { pe (Electron) }{ }^{(5)} \\
\text { Controlled } \\
\text { element }\end{array}$ & & & & $\begin{array}{l}\mathrm{SO}_{4}^{2-} / \mathrm{S}^{2-} \text { couple at } \\
\text { pyrite and siderite, } \\
\text { goethite or } \mathrm{Fe}(\mathrm{OH})_{3} \\
\text { (mic) saturation }\end{array}$ & $\begin{array}{l}\mathrm{SO}_{4}{ }^{2-} / \mathrm{S}^{2-} \text { couple at } \\
\text { pyrite and daphnite (Fe- } \\
\text { chlorite) saturation }\end{array}$ & $\begin{array}{l}\mathrm{SO}_{4}^{2-} / \mathrm{S}^{2-} \text { couple at } \\
\text { pyrite and daphnite (Fe- } \\
\text { chlorite) saturation }\end{array}$ & $\begin{array}{l}\mathrm{SO}_{4}{ }^{2-} / \mathrm{S}^{2-} \text { couple at } \\
\text { pyrite and siderite } \\
\text { saturation }\end{array}$ \\
\hline $\begin{array}{l}\quad \mathrm{pH}\left(\mathrm{H}^{+}\right)^{(5)} \\
\text { Controlled } \\
\text { element }\end{array}$ & $\begin{array}{l}\text { Solution electro- } \\
\text { neutrality }\end{array}$ & $\begin{array}{l}\text { Solution electro- } \\
\text { neutrality }\end{array}$ & $\begin{array}{l}\mathrm{P}_{\mathrm{CO} 2} \text { fixed at generic } \\
\text { value. Carbonate } \\
\text { species and TIC } \\
\text { calculated from } \mathrm{CO}_{3}{ }^{-2} \text {, } \\
\mathrm{P}_{\mathrm{CO} 2} \text {, and carbonate } \\
\text { equilibria }\end{array}$ & $\begin{array}{l}\text { Solution electro- } \\
\text { neutrality }\end{array}$ & $\begin{array}{l}\text { Illite-Mg } \\
\mathrm{K}_{0.85} \mathrm{Mg}_{0.25} \mathrm{Al}_{2.35} \mathrm{Si}_{3.4} \mathrm{O}_{10} \\
(\mathrm{OH})_{2}\end{array}$ & $\begin{array}{l}\text { Illite-Mg } \\
\mathrm{K}_{0.85} \mathrm{Mg}_{0.25} \mathrm{Al}_{2.35} \mathrm{Si}_{3.4} \mathrm{O}_{10} \\
(\mathrm{OH})_{2}, \\
\text { OR } \\
\text { Illite_Imt-2 } \\
\left(\mathrm{Na}_{0.044} \mathrm{~K}_{0.762}\right)\left(\mathrm{Si}_{3.387}\right. \\
\left.\mathrm{Al}_{0.613}\right)\left(\mathrm{Al}_{1.427} \mathrm{Fe}_{0.376}\right. \\
\left.\mathrm{Mg}_{0.241}\right) \mathrm{O}_{10}(\mathrm{OH})_{2},\end{array}$ & $\begin{array}{l}\text { Kaolinite, } \\
\text { illite-Mg, Illite Imt-2 } \\
\text { Mg-montmorillionite } \\
\text { Chlorite CCa-2 } \\
\text { OR } \\
\text { daphnite saturation }\end{array}$ \\
\hline $\begin{array}{l}\mathrm{Na}^{+} \\
\text {Controlled } \\
\text { element }\end{array}$ & Albite saturation & $\mathrm{Na}$ feldspar saturation & $\begin{array}{l}\text { Solution electro- } \\
\text { neutrality }\end{array}$ & $\mathrm{Na}-\mathrm{Ca}$ exchange ${ }^{*}$ & $\begin{array}{l}\text { Solution electro- } \\
\text { neutrality }\end{array}$ & $\begin{array}{l}\text { Solution electro- } \\
\text { neutrality }\end{array}$ & $\begin{array}{l}\text { Solution electro- } \\
\text { neutrality }\end{array}$ \\
\hline
\end{tabular}




\begin{tabular}{|c|c|c|c|c|c|c|c|}
\hline & $\begin{array}{c}\text { Coudrain-Ribstein and } \\
\text { Gouze (1993) } \\
\text { Tab } 1 \text { \& Fig } 5\end{array}$ & Beaucaire et al. (2000) & $\begin{array}{c}\text { Bradbury \& Baeyens } \\
\text { (1998) }\end{array}$ & $\begin{array}{l}\text { Pearson et al. }(2003) \\
\quad \text { Table } 5.8^{(4)}\end{array}$ & $\begin{array}{l}\text { COX Reference model } \\
\text { (Gaucher } \text { et al (2006, } \\
\text { 2009) }^{(1),(2)}\end{array}$ & $\begin{array}{l}\text { COX Alternate models } \\
\text { (Gaucher et al (2006, } \\
\text { 2009) }^{(1),(3)}\end{array}$ & $\begin{array}{l}\text { PC-C pore-water } \\
\text { calculation }\end{array}$ \\
\hline $\begin{array}{l}\qquad \mathrm{K}^{+} \\
\text {Controlled } \\
\text { element }\end{array}$ & K-feldspar saturation & $\begin{array}{l}\text { K feldspar saturation } \\
\text { Feldspar properties } \\
\text { chosen to match } \\
\text { regional }(\mathrm{Na}) /(\mathrm{H}) \text { and } \\
(\mathrm{K}) /(\mathrm{H})\end{array}$ & $\mathrm{Na}-\mathrm{K}$ exchange & Na-K exchange & $\mathrm{Na}-\mathrm{K}$ exchange & $\begin{array}{l}\mathrm{Na}-\mathrm{K} \text { exchange } \\
\mathrm{OR} \\
\text { Illite-Mg saturation }\end{array}$ & $\mathrm{Na}-\mathrm{K}$ exchange \\
\hline $\begin{array}{l}\qquad \mathrm{Ca}^{2+} \\
\text { Controlled } \\
\text { element }\end{array}$ & Calcite saturation & Calcite saturation & $\mathrm{Na}-\mathrm{Ca}$ exchange & Calcite saturation & $\mathrm{Na}-\mathrm{Ca}$ exchange & $\mathrm{Na}-\mathrm{Ca}$ exchange & $\mathrm{Na}-\mathrm{Ca}$ exchange ${ }^{*}$ \\
\hline $\begin{array}{l}\qquad \mathrm{Mg}^{2+} \\
\text { Controlled } \\
\text { element }\end{array}$ & Mg-chlorite saturation & Dolomite saturation & Dolomite saturation & $\begin{array}{l}\text { Dolomite saturation } \\
\text { AND (A3-E) } \\
\text { OR (A3-D) } \\
\mathrm{Na}-\mathrm{Mg} \text { exchange }\end{array}$ & Na-Mg exchange & $\begin{array}{l}\text { Dolomite } \\
\text { OR } \\
\text { Illite-Mg, } \\
\text { Illite_Imt-2 or } \\
\text { Mg-montmorillonite } \\
\text { saturation }\end{array}$ & $\begin{array}{l}\text { Dolomite } \\
\text { OR } \\
\text { Na-Mg exchange }\end{array}$ \\
\hline $\begin{array}{l}\qquad \mathrm{Sr}^{2+} \\
\text { Controlled } \\
\text { element }\end{array}$ & & & & $\mathrm{Na}-\mathrm{Sr}$ exchange & $\begin{array}{l}\mathrm{Na}-\mathrm{Sr} \text { exchange } \\
\text { ADJUSTED TO } \\
\text { Celestite saturation }\end{array}$ & $\begin{array}{l}\mathrm{Na}-\mathrm{Sr} \text { exchange } \\
\text { ADJUSTED TO } \\
\text { Celestite saturation }\end{array}$ & Celestite saturation \\
\hline $\begin{array}{l}\qquad \mathrm{F}^{-} \\
\text {Controlled } \\
\text { element }\end{array}$ & Fluorite saturation & & Fluorite saturation & & & & \\
\hline $\begin{array}{l}\qquad \mathrm{SiO}_{2} \\
\text { Controlled } \\
\text { element }\end{array}$ & Chalcedony saturation & Chalcedony saturation & Chalcedony saturation & Quartz saturation & Quartz saturation & Quartz saturation & Quartz saturation \\
\hline
\end{tabular}




\begin{tabular}{|c|c|c|c|c|c|c|c|}
\hline & $\begin{array}{c}\text { Coudrain-Ribstein and } \\
\text { Gouze (1993) } \\
\text { Tab } 1 \& \text { Fig } 5\end{array}$ & Beaucaire et al. (2000) & $\begin{array}{c}\text { Bradbury \& Baeyens } \\
\text { (1998) }\end{array}$ & $\begin{array}{c}\text { Pearson et al. }(2003) \\
\text { Table } 5.8 \\
\text { (4) }\end{array}$ & $\begin{array}{l}\text { COX Reference model } \\
(\text { Gaucher } \text { et al (2006, } \\
\text { 2009) }^{(1),(2)}\end{array}$ & $\begin{array}{c}\text { COX Alternate models } \\
\text { (Gaucher et al (2006, } \\
\text { 2009) }\end{array}$ & $\begin{array}{l}\text { PC-C pore-water } \\
\text { calculation }\end{array}$ \\
\hline $\begin{array}{l}\text { Al } \\
\text { Controlled } \\
\text { element }\end{array}$ & Kaolinite saturation & Kaolinite saturation & & $\begin{array}{l}\text { Kaolinite or halloysite } \\
\text { saturation }\end{array}$ & $\begin{array}{l}\text { Daphnite }(\mathrm{Fe} \text {-chlorite) } \\
\mathrm{Fe}_{5} \mathrm{Al}\left(\mathrm{AlSi} \mathrm{Al}_{3}\right) \mathrm{O}_{10}(\mathrm{OH})_{8} \\
\text { saturation }\end{array}$ & $\begin{array}{l}\text { Daphnite }(\mathrm{Fe}-\text {-chlorite }) \\
\mathrm{Fe}_{5} \mathrm{Al}\left(\mathrm{AlSi}_{3}\right) \mathrm{O}_{10}(\mathrm{OH})_{8} \\
\mathrm{OR} \\
\text { Chlorite_Cca-2 } \\
\mathrm{Mg}_{2.97} \mathrm{Fe}_{1.92}, \mathrm{Al}_{2,49} \\
\mathrm{Ca}_{0.01} \mathrm{Si}_{2.63} \mathrm{O}_{10}(\mathrm{OH})_{8} \\
\text { saturation }\end{array}$ & $\begin{array}{l}\text { Kaolinite, } \\
\text { illite-Mg, } \\
\text { Illite-Imt2 } \\
\text { Mg-montmorillionite } \\
\text { Chlorite CCa-2 } \\
\text { OR } \\
\text { daphnite saturation }\end{array}$ \\
\hline $\begin{array}{l}\mathrm{Fe} \\
\begin{array}{l}\text { Controlled } \\
\text { element }\end{array}\end{array}$ & & & & $\begin{array}{l}\text { Siderite, goethite (A3-F) } \\
\text { OR Fe(OH) }(\text { mic) (A3- } \\
\text { G) saturation }\end{array}$ & $\mathrm{Na}-\mathrm{Fe}(\mathrm{II})$ exchange & Siderite saturation & Siderite saturation \\
\hline $\begin{array}{l}\text { Mn } \\
\text { Controlled } \\
\text { element }\end{array}$ & & & & $\begin{array}{l}\text { Rhodochrosite } \\
\text { saturation }\end{array}$ & & & \\
\hline $\begin{array}{l}\text { U } \\
\text { Controlled } \\
\text { element }\end{array}$ & & & & $\mathrm{UO}_{2(\mathrm{~s})}$ saturation & & & \\
\hline
\end{tabular}

(1) Minerals and properties modelled are those included in THERMODDEM (BRGM) database. See: Gaucher et al. (2009) Electronic Annex 1 or http://thermoddem.brgm.fr/index.asp?langue $=\mathrm{GB}$

(2) These associations are based on Electronic Annex 3 of Gaucher et al. (2009) and are consistent with Table 4 of that paper.

(3) These associations are based on Electronic Annex 4 of Gaucher et al. (2009) and are not entirely consistent with Table 4 of that paper.

(4) Designations in parentheses refer to modelling variations shown in Fig. 4 \& 5 and discussed in Sect. 2.1.3.2 \& 2.1.3.3.

(5) Korzhinski (1965) specifies $\mathrm{H}^{+}$and $\mathrm{e}^{-}$as mobile components, but this is an ad hoc choice. His equations and those of Thompson (1955) show that any component can be mobile. 
Table 3 Exchangeable cation exchange populations measured on Opalinus Clay core samples from Mont Terri.

\begin{tabular}{|c|c|c|c|c|c|}
\hline & \multicolumn{2}{|c|}{$\begin{array}{c}\text { Measured on core } \\
\text { samples (Pearson et } \\
\text { al., 2003, Tab A3- } \\
\text { 11) }\end{array}$} & $\begin{array}{c}\text { Used in modelling by } \\
\text { Pearson et al. (2003) }\end{array}$ & $\begin{array}{c}\text { Measured on PC } \\
\text { core samples } \\
\text { Koroleva et al., } \\
\text { This issue) }\end{array}$ & $\begin{array}{c}\text { Used in PC-C } \\
\text { modelling, Sect, } \\
2.2 .4 .2\end{array}$ \\
\hline $\mathrm{NaX}$ & 0.485 & 0.015 & 0.5 & 0.51 & 0.51 \\
\hline $\mathrm{KX}$ & 0.062 & 0.005 & 0.08 & 0.09 & 0.09 \\
\hline $\mathrm{MgX} 2$ & 0.182 & 0.008 & 0.17 & 0.19 & 0.19 \\
\hline $\mathrm{CaX} 2$ & 0.274 & 0.019 & 0.24 & 0.21 & 0.21 \\
\hline $\mathrm{SrX} 2$ & 0.010 & 0.001 & 0.01 & & \\
\hline & & & & & \\
\hline $\mathrm{MgX} / \mathrm{CaX}$ & 0.66 & & 0.71 & -0.04 & -0.04 \\
\hline $\log \left(\mathrm{E}_{\mathrm{Mg}} / \mathrm{E}_{\mathrm{Ca}}\right)$ & -0.18 & & -0.15 & & \\
\hline
\end{tabular}


Table 4 Cation exchange selectivity coefficients measured and used in modelling pore waters from the Opalinus Clay at Mont Terri and the COx at Bure.

\begin{tabular}{|c|c|c|c|c|c|c|c|}
\hline & \multicolumn{5}{|c|}{ Pearson et al. (2003) table 5.3} & \multirow{3}{*}{$\begin{array}{c}\text { Used in PC-C } \\
\text { modelling } \\
\text { section } \\
2.2 .4 .2\end{array}$} & \multirow{3}{*}{$\begin{array}{l}\text { Used for COx } \\
\text { modelling in } \\
\text { Gaucher et al } \\
\text { (2009), Table } \\
3\end{array}$} \\
\hline & \multicolumn{4}{|c|}{ Measured on Opalinus Clay samples by: } & \multirow{2}{*}{$\begin{array}{c}\text { Generic } \\
\text { values given } \\
\text { in PHREEQC } \\
\text { database and } \\
\text { used for } 2003 \\
\text { modelling of } \\
\text { BWS A-1 and } \\
\text { A-3 }\end{array}$} & & \\
\hline & Unibern & CIEMAT & PSI & BRGM & & & \\
\hline $\log \mathrm{Na} / \mathrm{K}$ & 0.75 & 0.84 & 0.7 & 0.63 & 0.7 & 1.4 & 1.2 \\
\hline $\log \mathrm{Na} / \mathrm{Mg}$ & 0.57 & 0.6 & 0.59 & 0.62 & 0.6 & 0.7 & 0.7 \\
\hline $\log \mathrm{Na} / \mathrm{Ca}$ & 0.7 & 0.79 & 0.67 & 0.8 & 0.8 & 0.7 & 0.7 \\
\hline $\log \mathrm{Na} / \mathrm{Sr}$ & 0.47 & 0.71 & & & 0.91 & 0.7 & 0.6 \\
\hline $\log \mathrm{Na} / \mathrm{Fe}$ & & & & & 0.44 & 0.7 & 0.8 \\
\hline
\end{tabular}




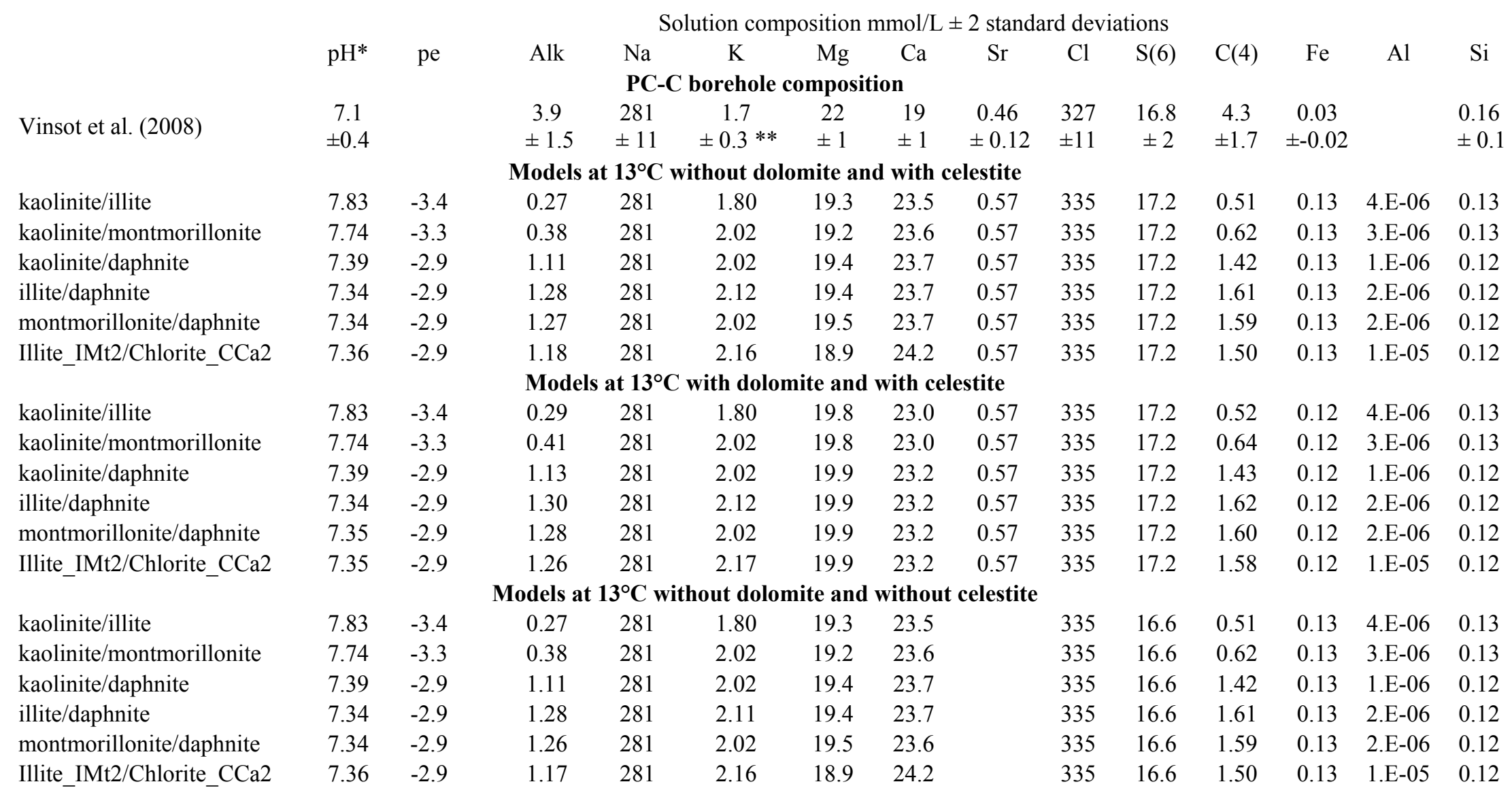

$* \mathrm{pH}$ values of $\mathrm{PC}-\mathrm{C}$ samples were measured at $20^{\circ} \mathrm{C}$ in the lab

** One high value neglected in the table from Vinsot et al. (2008) 
Table 6 Comparison of exchanger composition and saturation indices with modelled one using various mineralogical assemblages. Calculations were performed with BRGM THERMODDEM database.

\begin{tabular}{|c|c|c|c|c|c|c|c|c|c|c|}
\hline \multicolumn{5}{|c|}{ Exchanger composition } & \multicolumn{6}{|c|}{ Saturation indices } \\
\hline $\mathrm{E}_{\mathrm{Ca}}$ & $\mathrm{E}_{\mathrm{Mg}}$ & $\mathrm{E}_{\mathrm{Sr}}$ & $\mathrm{E}_{\mathrm{K}}$ & $\mathrm{E}_{\mathrm{Na}}$ & Calcite & Dolomite & Siderite & Celestite & Gypsum & Quartz \\
\hline & & & & PC & compositio & & & & & \\
\hline 0.21 & 0.19 & & 0.09 & 0.51 & $0.1+/-0.5^{*}$ & $0.4+/-1 *$ & $-0.6+/-0.4$ & $-0.1+/-0.1$ & $-0.46+/-0.04$ & $0.1+/-0.3$ \\
\hline
\end{tabular}

kaolinite/illite

kaolinite/montmorillonite kaolinite/daphnite

illite/daphnite

montmorillonite/daphnite

Illite_IMt2/Chlorite_CCa2

kaolinite/illite

kaolinite/montmorillonite

kaolinite/daphnite

illite/daphnite

montmorillonite/daphnite

Illite_IMt2/Chlorite_CCa2

\section{kaolinite/illite}

kaolinite/montmorillonite

kaolinite/daphnite

illite/daphnite

montmorillonite/daphnite

Illite IMt2/Chlorite CCa2

Models at $13^{\circ} \mathrm{C}$ without dolomite and with celestite

\begin{tabular}{llllllc}
\multicolumn{1}{c}{ Models at $\mathbf{1 3}^{\circ} \mathbf{C}$ without dolomite and with celestite } \\
0.22 & 0.19 & 0.005 & 0.08 & 0.51 & 0 & -0.02 \\
0.22 & 0.18 & 0.005 & 0.09 & 0.50 & 0 & -0.03 \\
0.22 & 0.19 & 0.005 & 0.09 & 0.50 & 0 & -0.02 \\
0.22 & 0.19 & 0.005 & 0.09 & 0.50 & 0 & -0.02 \\
0.22 & 0.19 & 0.005 & 0.09 & 0.50 & 0 & -0.02 \\
0.22 & 0.18 & 0.005 & 0.09 & 0.50 & 0 & -0.04
\end{tabular}

Models at $13^{\circ} \mathrm{C}$ with dolomite and with celestite

$\begin{array}{lllllll}0.22 & 0.19 & 0.005 & 0.08 & 0.51 & 0 & 0 \\ 0.21 & 0.19 & 0.005 & 0.09 & 0.50 & 0 & 0 \\ 0.21 & 0.19 & 0.005 & 0.09 & 0.50 & 0 & 0 \\ 0.21 & 0.19 & 0.005 & 0.09 & 0.50 & 0 & 0 \\ 0.21 & 0.19 & 0.005 & 0.09 & 0.50 & 0 & 0 \\ 0.21 & 0.19 & 0.005 & 0.09 & 0.50 & 0 & 0\end{array}$

$\begin{array}{lllll}0.21 & 0.19 & 0.005 & 0.09 & 0.50\end{array}$

Models at $13^{\circ} \mathrm{C}$ without dolomite and without celestite

$\begin{array}{llllll}0.22 & 0.19 & 0.08 & 0.51 & 0 & -0.02 \\ 0.22 & 0.19 & 0.09 & 0.51 & 0 & -0.03 \\ 0.22 & 0.19 & 0.09 & 0.51 & 0 & -0.02 \\ 0.22 & 0.19 & 0.09 & 0.50 & 0 & -0.02 \\ 0.22 & 0.19 & 0.09 & 0.51 & 0 & -0.02 \\ 0.22 & 0.18 & 0.09 & 0.50 & 0 & -0.04\end{array}$

* for the five last sampling points, mean calcite saturation index is $-0.02+/-0.2$ and mean dolomite saturation index is $0.1+/-0.4$. 


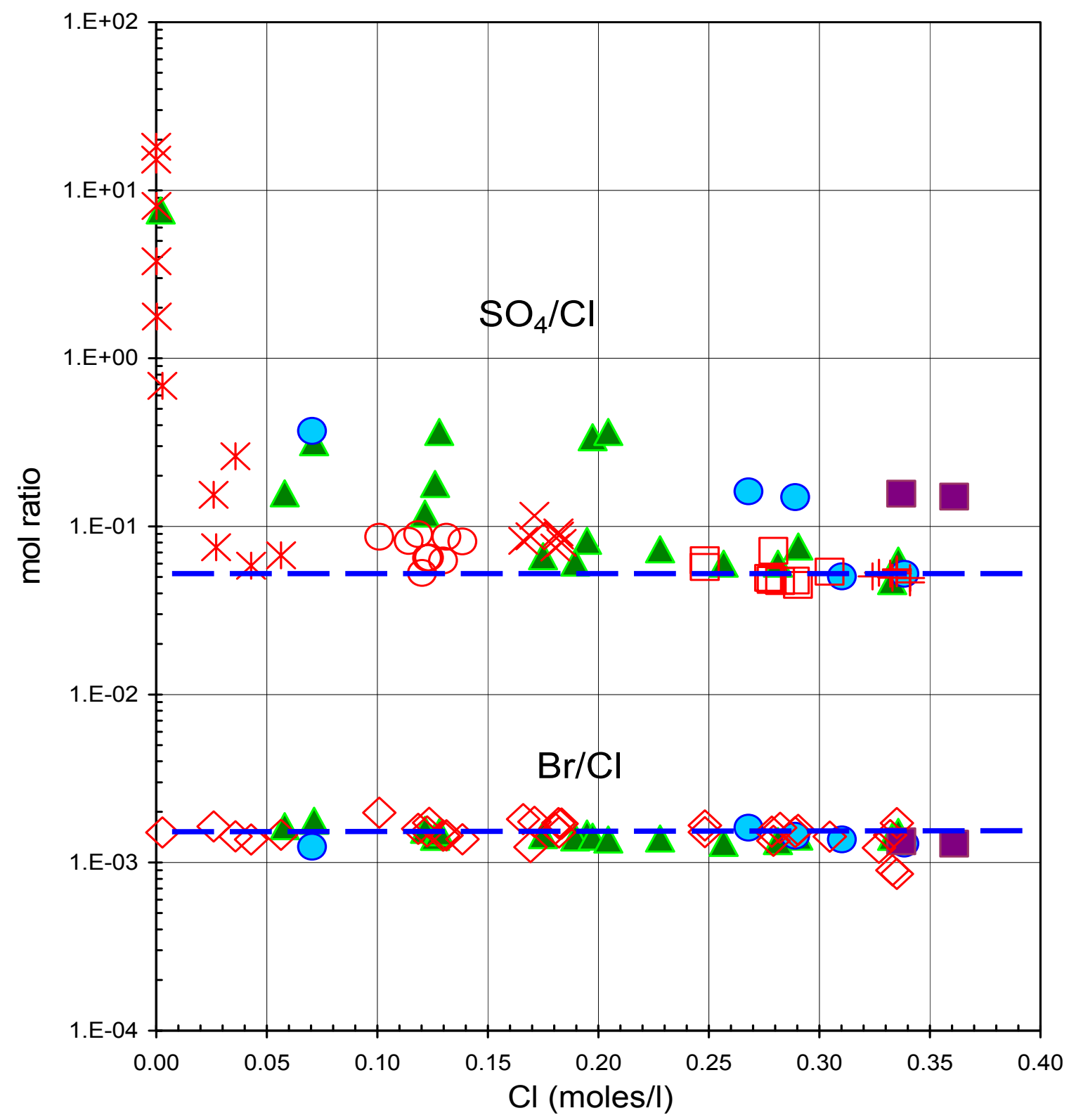

\begin{tabular}{lll|}
\hline$\triangle$ BGS Squeezing & OCIEMAT Squeezing & $\square$ CRIEPI Squeezing \\
$\square$ BWSA-1 & $\times$ BWSA-2 & OBWSA-3 \\
* Seeps & + PC-C & $\diamond$ All Boreholes $(\mathrm{Br} / \mathrm{Cl})$ \\
\hline
\end{tabular}

Figure 1: Comparison of sulphate/chloride and bromide/chloride ratios with chloride contents of borehole and squeezed water samples. Dashed lines represent the respective ratios in seawater. Data on borehole samples and water squeezed from core from various laboratories from June 1997 through February 2000 as reported by Pearson et al. (2003) and on PC-C borehole samples from Vinsot et al. (2008). 


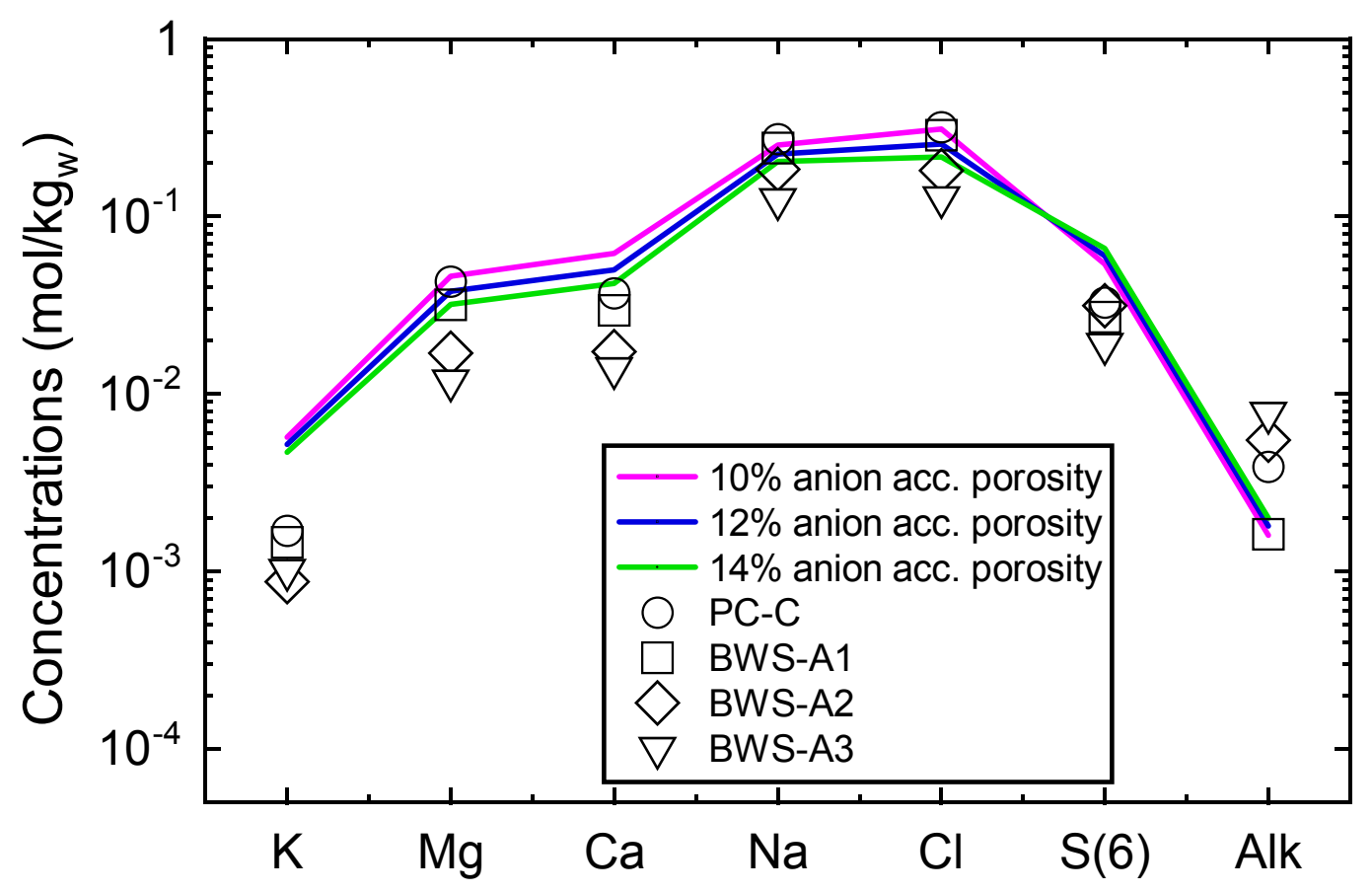

Figure 2: Schoeller diagram comparing major ion compositions measured in samples from Mont Terri boreholes and shown in Table 1 with compositions calculated by Bradbury and Baeyens (1998) at three assumed values of anion-accessible porosities. Alkalinity (Alk) is given as $\mathrm{HCO}_{3}^{-}, \mathrm{S}(6)$ represents sulphate. 


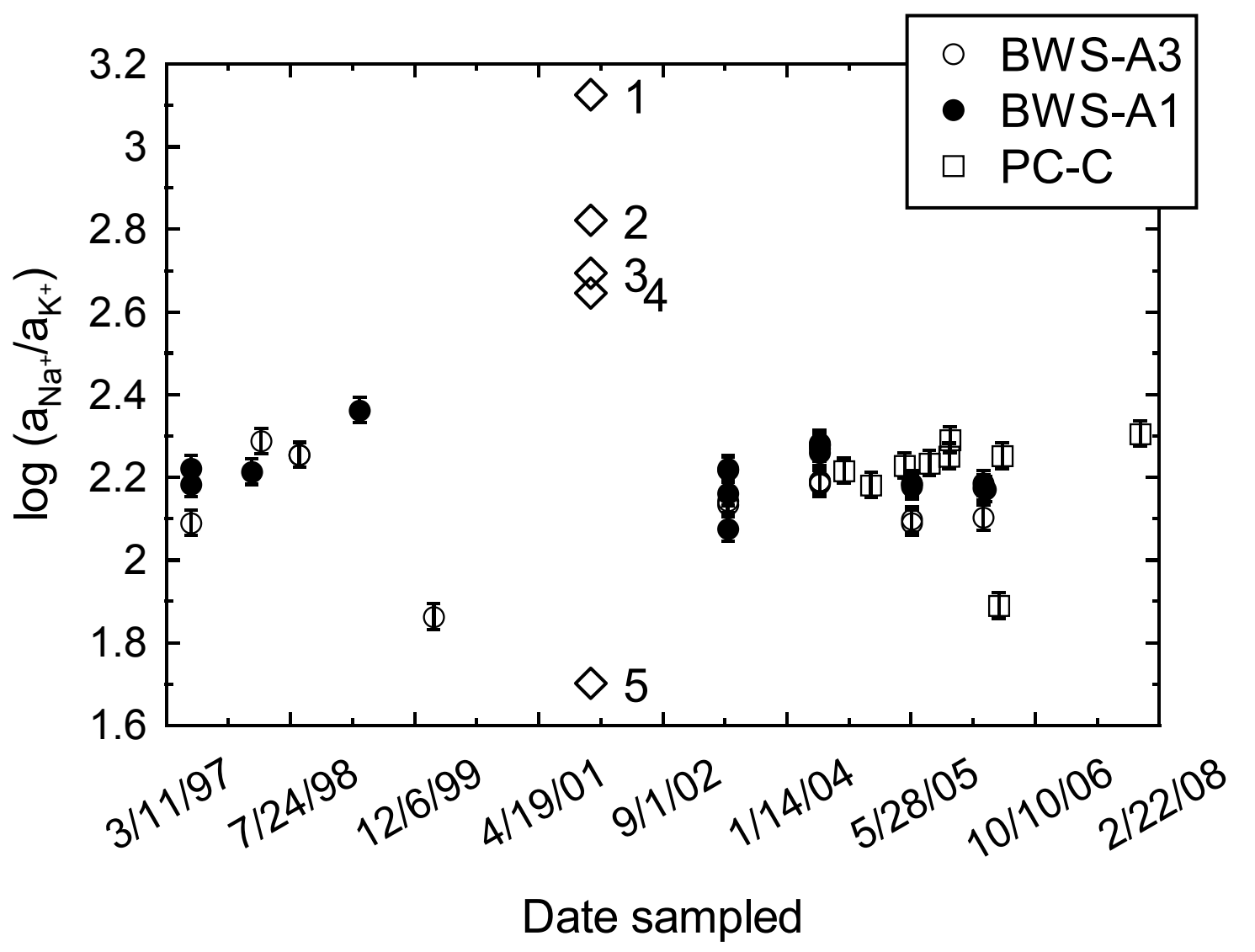

Figure 1 Comparison of potassium/sodium ratios measured in Mont Terri borehole waters (circles and squares) with ratios calculated using thermodynamic data for albite and K-feldspar from various compilations of thermodynamic data (diamonds). 1: value from SUPCRT (from PHREEQC 1lnl.dat). 2: value from Stefansson and Arnorsson (2000, table 2). 3: value from THERMODDEM database. 4: value from Coudrain-Ribstein and Gouze (1993, Table 2) and Michard (1983). 5: value from Beaucaire et al. (2000, table 4). 


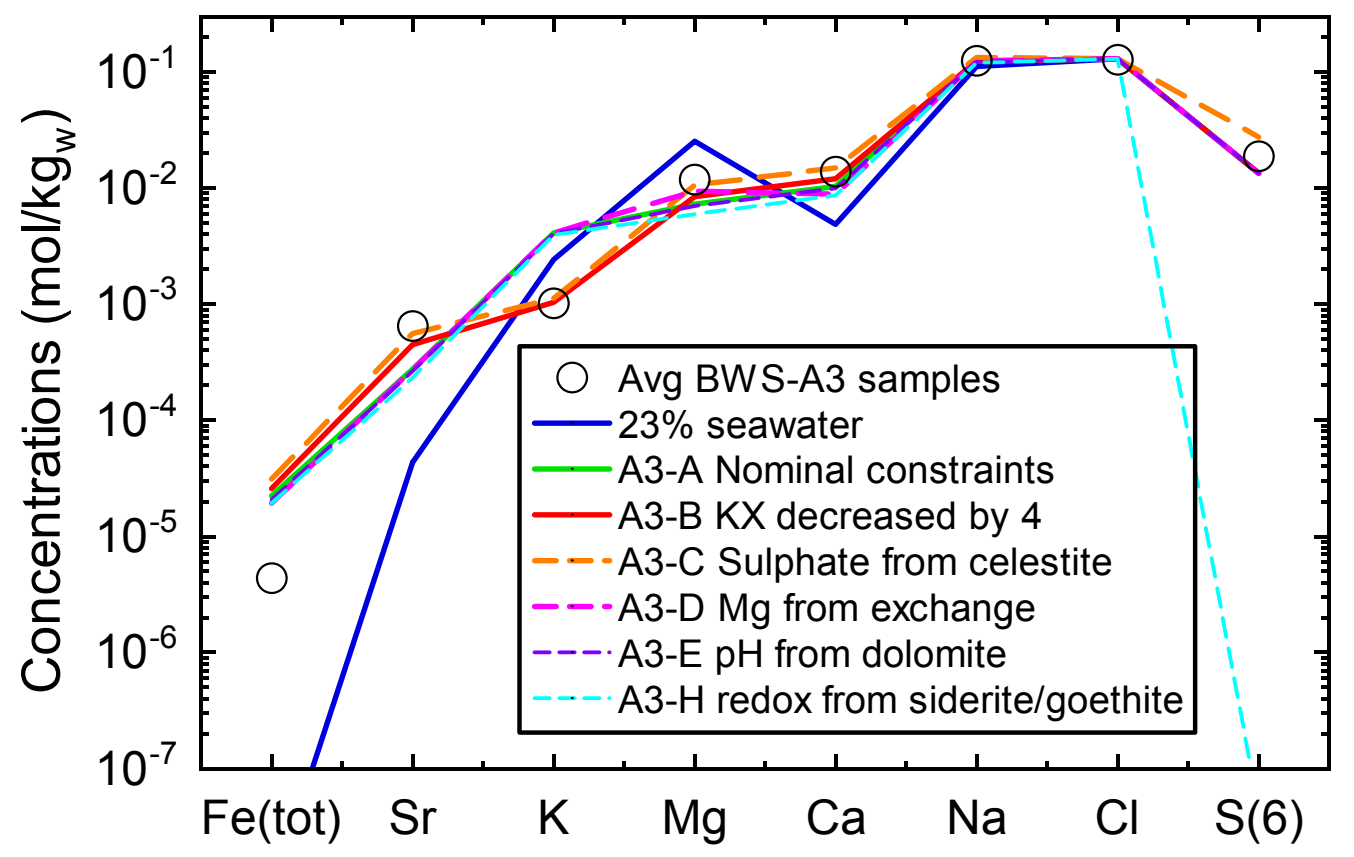

Figure 2 Schoeller diagram comparing average measured BWSA-3 major solute compositions with results of models with different constraints. Designations of constraint sets refer to Table 5.10 of Pearson et.al. (2003) and are given in the text. 


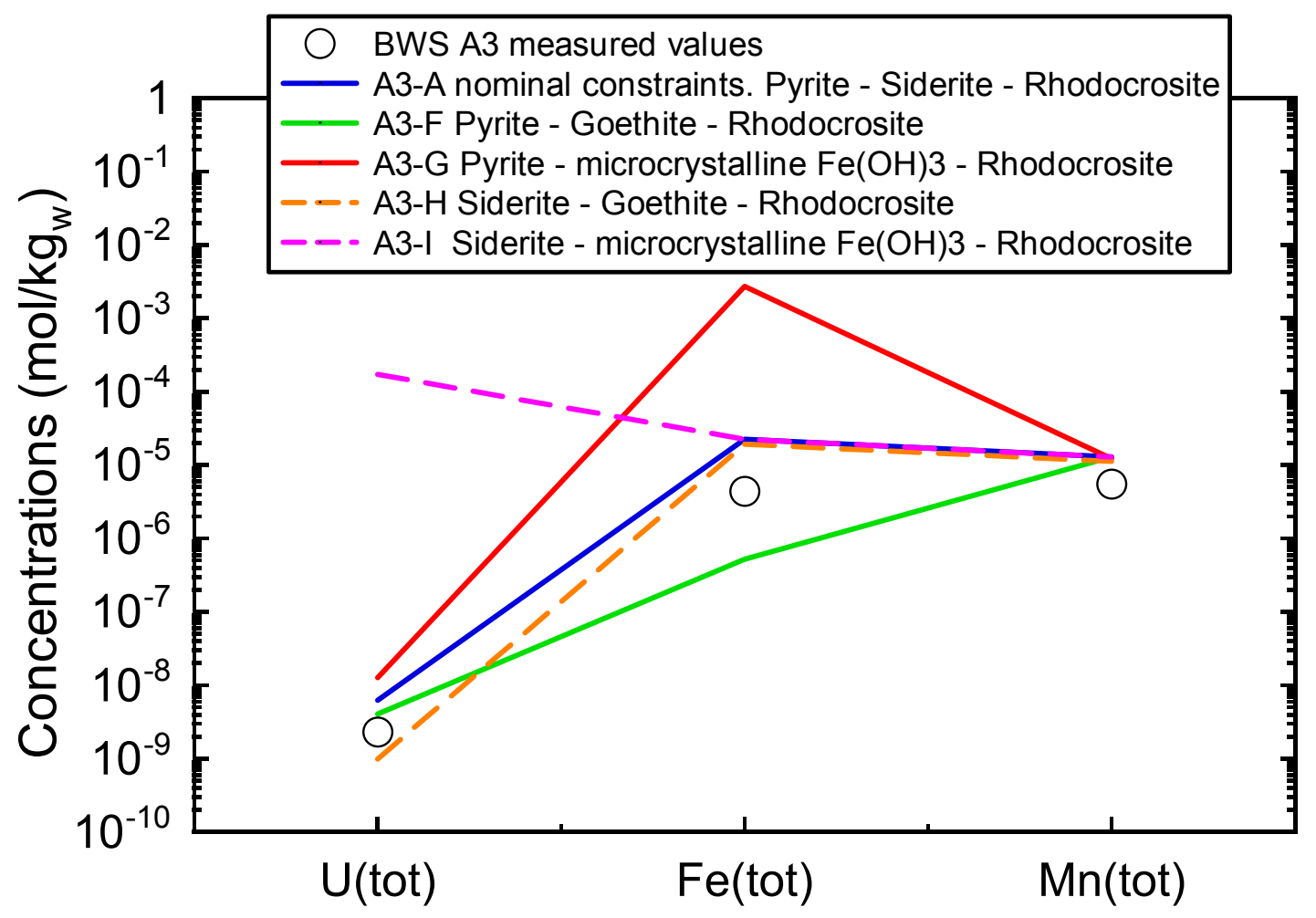

Figure 3 Schoeller diagram comparing average measured BWSA-3 redox-sensitive solute concentrations with results of models with different constraints. Designations of constraint sets refer to Table 5.10 of Pearson et.al.(2003) and are given in the text. 


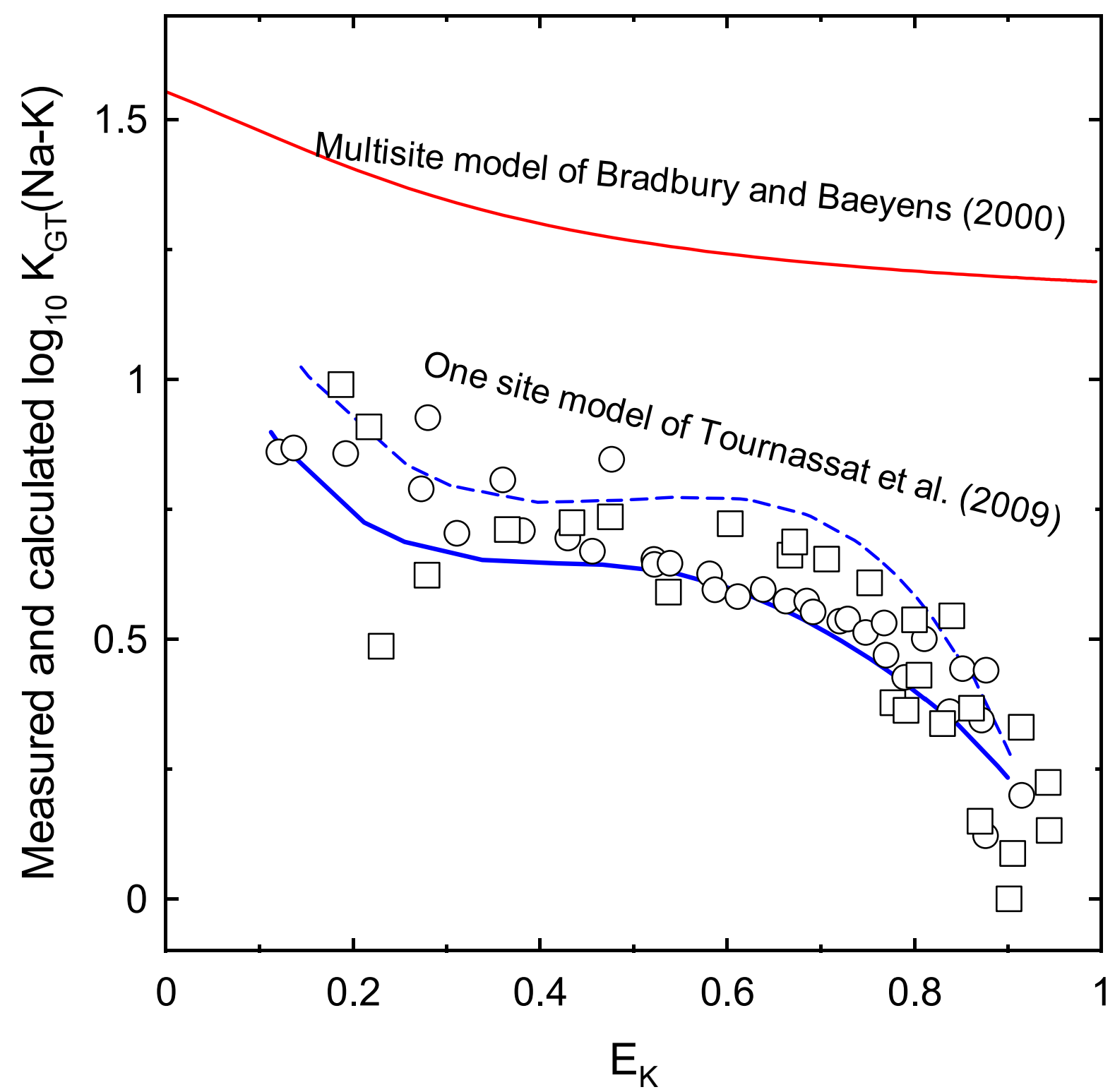

Figure 6 Comparison of measured and calculated $\mathrm{Na} / \mathrm{K}$ exchange selectivity coefficients as a function of $\mathrm{K}$ occupancy on Source Clay illite Imt-2 (square: data; dashed blue line: model from Tournassat et al., 2009) and $<2 \mu \mathrm{m}$ fraction of Opalinus clay from Mont Terri (circles: data; plain blue line model from Tournassat et al., 2009) Modified from figure 15 in Tournassat et al., 2009. Prediction using the model from Bradbury and Baeyens (2000) is given for comparison (red plain line). 


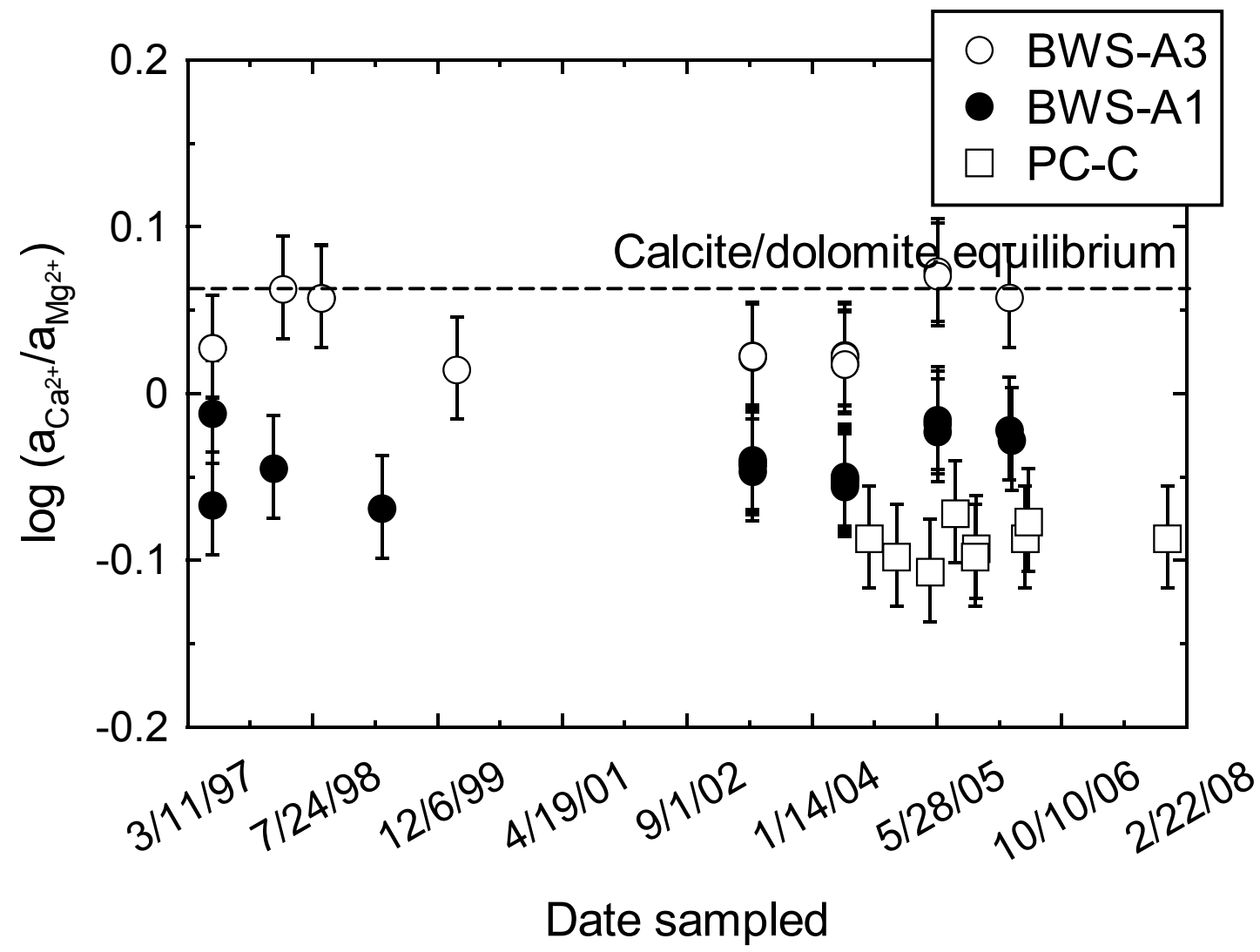

Figure 4 Activity ratios of $\mathrm{Ca}^{2+}$ to $\mathrm{Mg}^{2+}$ calculated for samples from the PC-C, BWS-A1 and BWS-A3 boreholes using the Thermoddem database (BRGM). Calculations were made at sample temperatures, which range from 10 to $13^{\circ} \mathrm{C}$. The value for $\left(2 \log \mathrm{K}_{\text {calcite }}-\log \mathrm{K}_{\text {dolomite }}\right)$ corresponds to $13^{\circ} \mathrm{C}$. The bars on the values represent $2 \mathrm{SD}$ for 5\% analytical error on $\mathrm{Ca}$ and $\mathrm{Mg}$ measurements. 